\title{
Synthesis of polycyclic aromatic hydrocarbons via benzannulated enediynyl alcohols
}

\author{
Elbin Sehnaz Parbin \\ West Virginia University
}

Follow this and additional works at: https://researchrepository.wvu.edu/etd

\section{Recommended Citation}

Parbin, Elbin Sehnaz, "Synthesis of polycyclic aromatic hydrocarbons via benzannulated enediynyl alcohols" (2007). Graduate Theses, Dissertations, and Problem Reports. 2539.

https://researchrepository.wvu.edu/etd/2539

This Thesis is protected by copyright and/or related rights. It has been brought to you by the The Research Repository @ WVU with permission from the rights-holder(s). You are free to use this Thesis in any way that is permitted by the copyright and related rights legislation that applies to your use. For other uses you must obtain permission from the rights-holder(s) directly, unless additional rights are indicated by a Creative Commons license in the record and/ or on the work itself. This Thesis has been accepted for inclusion in WVU Graduate Theses, Dissertations, and Problem Reports collection by an authorized administrator of The Research Repository @ WVU. For more information, please contact researchrepository@mail.wvu.edu. 


\title{
Synthesis of Polycyclic Aromatic Hydrocarbons via Benzannulated Enediynyl Alcohols
}

\section{Elbin Sehnaz Parbin}

\author{
Dissertation \\ Submitted to the Eberly College of Arts and Sciences \\ at \\ West Virginia University \\ in partial fulfillment of the requirements for the degree of \\ Master of Science \\ in Organic Chemistry
}

Kung K. Wang, Ph. D., Advisor

George A. O’Doherty, Ph. D.

Jeffrey L. Petersen, Ph. D.

C. Eugene Bennett Department of Chemistry

Morgantown, West Virginia

2007

Keyword: Schmittel Cyclization, Enyne-Allenes, Biradical 


\section{ABSTRACT \\ Synthesis of Polycyclic Aromatic Hydrocarbons via Benzannulated Enediynyl Alcohols}

\section{Elbin Sehnaz Parbin}

Under mild conditions, a derivative of $11 \mathrm{H}$-benzo[b]fluorine 76, was successfully synthesized through tandem cyclization of the corresponding enediynyl propargylic alcohol, 69. Condensation of the substituted indanone 67 with the lithium acetylide 23 furnished benzannulated enediynyl propargylic alcohol 69 in 1:1 diastereomeric ratio. Reduction of propargylic alcohol 69 with triethylsilane in the presence of trifluoroacetic acid gave benzannulated enediynes 70. Treatment of $\mathbf{7 0}$ with potassium tert-butoxide in refluxing toluene furnished alkene 74. Hydroboration of alkene $\mathbf{7 4}$ followed by iodination in the presence of base produced alkyl iodide 75 . The alkyl iodide 75 with treatment of potassium tert-butoxide in THF underwent intramolecular cyclization, producing the polycyclic aromatic hydrocarbon $\mathbf{7 6}$ in $18 \%$ overall yield from substituted indanone $\mathbf{6 7}$. 


\section{DEDICATED TO}

My husband, my brother, and my parents 


\section{ACKNOWLEDGEMENTS}

It gives me an immense pleasure and pride to express my sincere gratitude and respect for my advisor, Dr. Kung K. Wang, for his support, patience, constant encouragement and practical suggestions throughout my graduate studies. His mentorship was essential to the completion of this dissertation.

I take this opportunity to thank my research committee members, Dr. George A. O’Doherty and Dr. Jeffrey L. Petersen for their valuable comments and suggestions that improved the contents of this dissertation.

My special thanks go to Dr. Novruz Akhmedov for his help with the NMRs and nOe structure analysis of my compounds.

My very special appreciation goes to Sanjeeva Rao Guppi and Daehwan Kim for their help, suggestions and discussions.

I would also like to thank the former and present group members, Dr. Weixiang Dai, Dr. Hua Yang, Lily Wang, Hu Cui, Bo Wen, and Ruoxin Zhang for their help and support.

I take the opportunity to thank the entire faculty, staff, and graduate students for their encouragement and help in a variety of ways.

I feel fortunate to have my husband Dr. Mohammed M. Ahmed, who always stood by me during the period of crisis and made me to realize my strength to face trouble and difficulties.

Special appreciation and gratitude are due to my parents, in-laws, brother, and my cute daughter Mehreen for their constant support and love.

Financial support from the C. Eugene Bennett Department of Chemistry at West Virginia University is gratefully acknowledged. 


\section{TABLE OF CONTENTS}

Title Page $\quad$ i

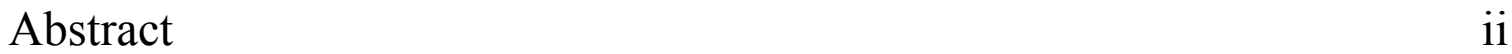

$\begin{array}{ll}\text { Dedications } & \text { iii }\end{array}$

Acknowledgements iv

Table of Contents $\quad$ v

Experimental Section $\quad$ vi

List of Figures vii

\section{Part I}

Synthesis of Polycyclic Aromatic Hydrocarbons via Benzannulated Enediynyl Alcohols

1. Introduction 1

2. Research Objective 4

3. Literature Survey for the Synthesis of $11 H$-Benzo $(b)$ fluorenes and Its Derivatives 4

4. Result and Discussion 15

5. Conclusions 22 


\section{Part II}

\section{Experimental Section}

General Methods and Materials

References

Appendix $\left({ }^{1} \mathrm{H}\right.$ NMR, ${ }^{13} \mathrm{C}$ NMR and IR Spectra $)$

${ }^{1} \mathrm{H}$ NMR and ${ }^{13} \mathrm{C}$ NMR of 2-Methoxy-1-iodoethane 59

$38-39$

${ }^{1} \mathrm{H}$ NMR and ${ }^{13} \mathrm{C}$ NMR of 2,3-dihydro-3-(2-methoxyethyl)inden-1-one 62

${ }^{1} \mathrm{H}$ NMR, ${ }^{13} \mathrm{C}$ NMR and IR Spectra of 2,3-dihydro-2,2-dimethyl

-3-(2-methoxyethyl)inden-1-one/2,3-dihydro-2-methyl-3-

(2-methoxyethyl)inden-1-one 64/63

${ }^{1} \mathrm{H}$ NMR, ${ }^{13} \mathrm{C}$ NMR and IR Spectra of 2-allyl-2,3-dihydro-2-methylinden-1-one 67

${ }^{1} \mathrm{H}$ NMR, ${ }^{13} \mathrm{C}$ NMR and IR Spectra of propargylic alcohol 69

${ }^{1} \mathrm{H}$ NMR, ${ }^{13} \mathrm{C}$ NMR and IR Spectra of diacetylenic hydrocarbon 70

54-56

${ }^{1} \mathrm{H}$ NMR, ${ }^{13} \mathrm{C}$ NMR and IR Spectra of alkene 74

${ }^{1} \mathrm{H}$ NMR, ${ }^{13} \mathrm{C}$ NMR and IR Spectra of $11 H$-benzo[b]fluorene iodide 75

${ }^{1} \mathrm{H}$ NMR, ${ }^{13} \mathrm{C}$ NMR and IR Spectra of polycyclic aromatic hydrocarbon 76 


\section{LIST OF FIGUURES}

Figure 1. Several examples of these bowl-shaped hydrocarbons

Figure 2. Comparison of $11 H$-benzo[b]fluorene (7) with

other buckybowls

3

Figure 3. nOe drawing of 62

Figure 4. nOe drawing of 63

Figure 5. nOe drawing of 64

Figure 6. nOe drawing of $\mathbf{7 6}$ 


\section{Part I}

\section{Synthesis of Polycyclic Aromatic Hydrocarbons via Benzannulated Enediynyl Alcohols}

\section{Introduction:}

In $1985, \mathrm{C}_{60}$ (buckyball), buckminsterfullerene ${ }^{1}$ was discovered by $\mathrm{H}$. W. Kroto (University of Sussex, UK), R. F. Curl and R. E. Smalley (both from Rice University, USA) and the Nobel Prize in Chemistry for the year 1996 was awarded to them. The $\mathrm{C}_{60}$ (buckyball) was named as "Molecule of the Year" by Science in $1991^{2}$. Since then there has been an extensive research activities going on to explore its chemical reactivities and physical properties and to develop new synthetic routes for $\mathrm{C}_{60}$ (buckyball). It is astonishing that buckyball and the related fullerene family have attracted this kind of attention from physicists, material scientists, and inorganic as well as organic chemists. ${ }^{3}$ Buckminsterfullerene and other higher fullerenes were isolated from soot produced by the vaporization of graphite in macroscopic quantity, access to this molecules facilitated the research activities. It is still remain a challenge for chemist to synthesize buckminsterfullerene and other higher fullerenes.

One of the most prevalent synthetic strategies to reach this goal is to first prepare curved hydrocarbon fragments (buckybowls) having the carbon 
frameworks represented on the surface of buckyball. ${ }^{3,4}$ Interestingly more than two decades prior to the discovery of $\mathrm{C}_{60}$ (buckyball), ${ }^{5}$ in 1966, Barth and Lawton first reported the synthesis of corannulene $\left(\mathrm{C}_{20} \mathrm{H}_{10}\right) \mathbf{1},{ }^{4 \mathrm{~b}, 6}$ the minimal structural subunit with a curvature of a fullerene. Later on several other examples of these bowl-shaped hydrocarbons, for instance benzo[a]acorannulene $\left(\mathrm{C}_{24} \mathrm{H}_{12}\right) 2,{ }^{4 \mathrm{a}, 4 \mathrm{~b}, 4 \mathrm{~d}}$ semibuckminsterfullerene $\left(\mathrm{C}_{30} \mathrm{H}_{12}\right)$ $3,{ }^{4 \mathrm{~d}, 6 \mathrm{~d}, 8}$ benzo $[g]$ acecorannulene $\left(\mathrm{C}_{26} \mathrm{H}_{12}\right) \quad 4{ }^{4 \mathrm{a}, 4 \mathrm{~d}}$ dibenzo $[a, g]$ corannulene $\left(\mathrm{C}_{28} \mathrm{H}_{14}\right) 5^{4 \mathrm{a}, 4 \mathrm{~b}, 7 \mathrm{a}, 7 \mathrm{~b}}$ and tribenzo[a,d,j]corannulene $\left(\mathrm{C}_{32} \mathrm{H}_{16}\right) \mathbf{6}^{4 \mathrm{a}, 6 \mathrm{~d}, 7 \mathrm{c}, 7 \mathrm{~d}}$ have been synthesized and characterized (figure 1).

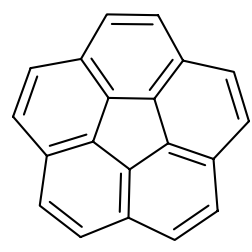

$\mathrm{C}_{20} \mathrm{H}_{10}, 1$

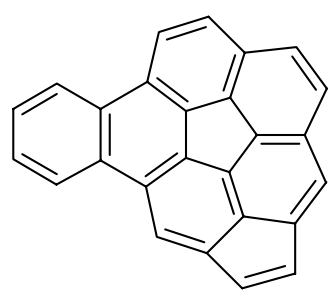

$\mathrm{C}_{26} \mathrm{H}_{12}, 4$

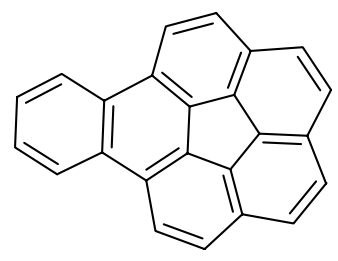

$\mathrm{C}_{24} \mathrm{H}_{12}, 2$

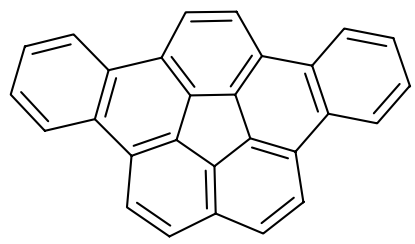

$\mathrm{C}_{28} \mathrm{H}_{14}, 5$

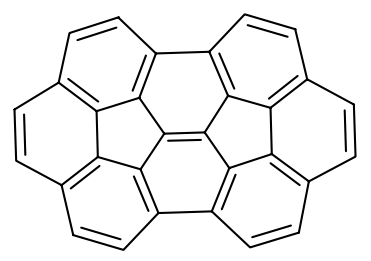

$\mathrm{C}_{30} \mathrm{H}_{12}, 3$

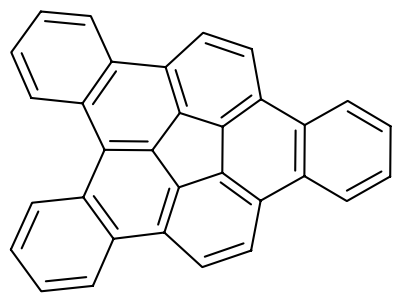

$\mathrm{C}_{32} \mathrm{H}_{16}, 6$

Figure 1 
Recently, the flash vacuum pyrolysis (FVP) method has been successful in providing more direct access to corannulene and several other buckybowls. However, FVP normally requires heating the precursors to $1000{ }^{\circ} \mathrm{C}$ or higher and the yields of highly strained buckykowls are very low, usually below $5 \%$ and sometimes even below $1 \%{ }^{3,4}$ Presumably at this high temperature, buckybowls with more delicate structures and higher energies may not survive. More recently, several synthetic efforts were reported in the literature ${ }^{6 \mathrm{~b}-\mathrm{c}, 8 \mathrm{~d}, 9 \mathrm{a}-\mathrm{c}}$ by using non-pyrolytic pathways to prepare buckybowls. To synthesize buckybowls which have five-membered rings surrounded by six-membered rings, it is not hard to imagin that benzofluorene, 7 and its derivatives can be used as potential precursors by comparing their structures with corannulenes and other buckybowls (figure 2). ${ }^{3,4,9}$
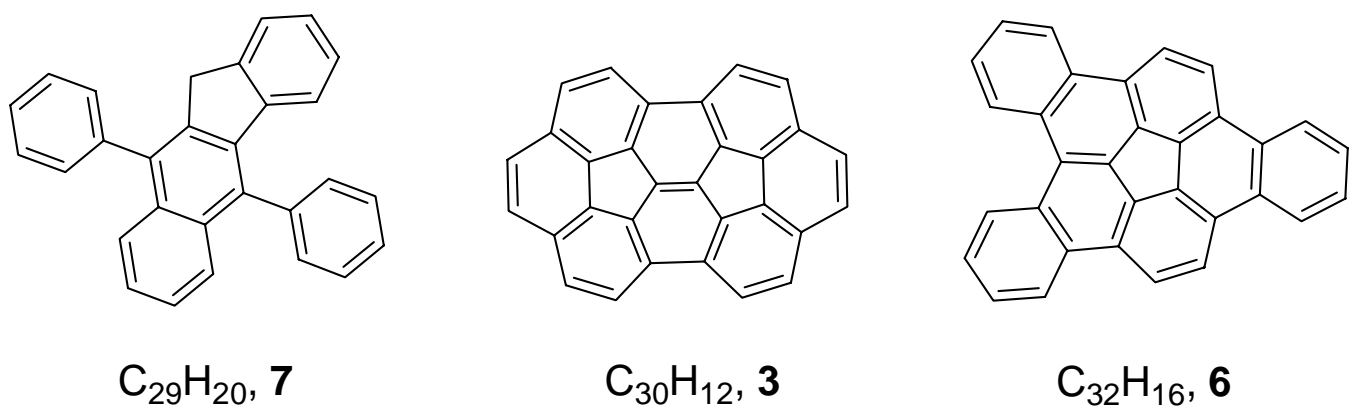

Figure 2 


\section{Research Objective}

Based on our previous discovery about the synthesis of $11 \mathrm{H}$ benzo[b]fluorene derivatives involving condensation of benzannulated enediynes and arylketones to produce benzannulated enediynyl propargylic alcohols followed by reduction and a sequence of cascade cyclization reactions, ${ }^{10}$ we envisioned that by using different combinations of benzannulated enediynes and arylketones for condensations, it is possible that a variety of other polycyclic aromatic hydrocarbons could also likewise be synthesized. We also hypothesized that by introducing $\mathrm{sp}^{3}$-hybridized carbons into the skeleton of the substrate the structure of buckybowl would be less strained, allowing the connection of properly situated carbon atoms.

\section{Literature Survey for the Synthesis of $11 H$-Benzo[b]fluorene and Its}

\section{Derivatives}

$11 H$-Benzo $[b]$ fluorene (7) and its derivatives attracted our interest because of their potentiality to be used as precursors for the synthesis of polycyclic aromatic hydrocarbons with carbon frameworks represented on the surface of $\mathrm{C}_{60}$.

Our group reported several novel synthetic pathways for the synthesis of several derivatives of $11 \mathrm{H}$-Benzo[b]fluorenes and the synthetic route relied on the enyne-allene cyclizations. ${ }^{10}$ Enyne-allenes can undergo either 
Myers-Saito cyclizations ${ }^{11}$ (C2-C7) or Schmittel cyclizations ${ }^{12}$ (C2-C6). In a simple system such as enyne-allene $\mathbf{8}$, the cyclization pathway depends on the alkynyl terminus substituent $\mathrm{R}$ (Scheme 1 ). When $\mathrm{R}$ is a proton or a $1^{\circ}$ alkyl group, such as the methyl group or the ethyl group, the enyne-allene favors the Myers-Saito cyclization pathway to produce the $\alpha, 3-$ didehydrotoluene/naphthalene biradical $\mathbf{9}$; when $\mathrm{R}$ is an aryl group or a sterically demanding group, such as the tert-butyl group or the trimethylsilyl group, the enyne-allene favors the Schmittel cyclization pathway to produce the fulvene/benzofulvene biradical 10.

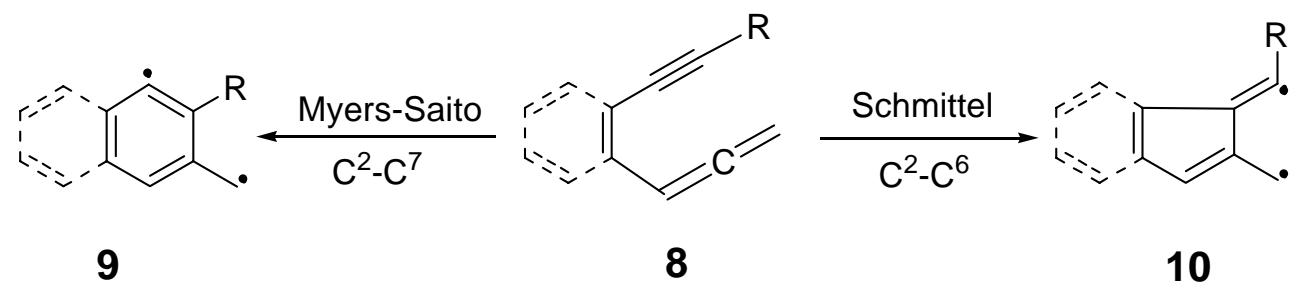

Scheme 1

Our group studied Myers-Saito cyclizations of (Z)-1,2,4-heptatrien-6ynes 11 (Scheme 2). ${ }^{13}$ If we compare to the parent (Z)-1,2,4-heptatrien-6yne, the rate of cycloaromatization of 11a is increased because of the formation of a more stable tertiary benzylic radical center in 12a, but in case of $11 \mathrm{~b}$ the rate of cycloaromatization is slow because of increased steric interactions due to tertiary butyl group although it forms more stable tertiary benzylic radical center in $\mathbf{1 2 b}$. 


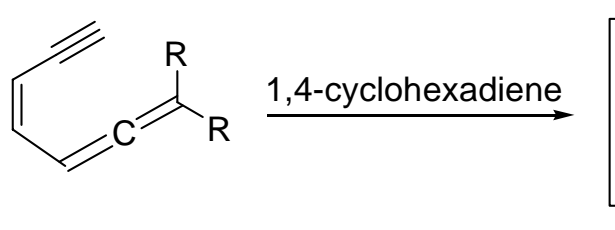

11a: $R=M e$

11b: $\mathrm{R}=t-\mathrm{Bu}$

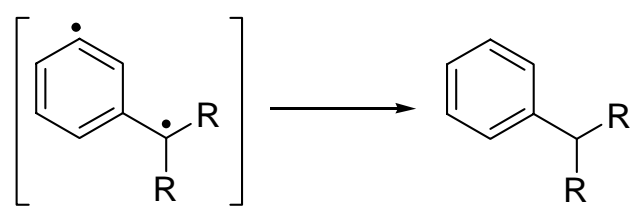

12a: $R=M e$

12b: $\mathrm{R}=t-\mathrm{Bu}$

13a: $R=M e, 43 \%$

13b: $\mathrm{R}=t-\mathrm{Bu}, 58 \%$

\section{Scheme 2}

Our group also studied the Schmittel cyclizations of $\mathbf{1 4}$ with a benzene tether connecting the alkyne and the allene moiety to produce the benzofulvene biradicals 15 (Scheme 3). ${ }^{10 \mathrm{f}}$ The aryl groups at the allenic terminus of the enyne-allene system could further participate in an intramolecular radical-radical coupling to form the formal Diels-Alder adducts 16, and subsequently after tautomerization, gave the tetracyclic hydrocarbon 17. 


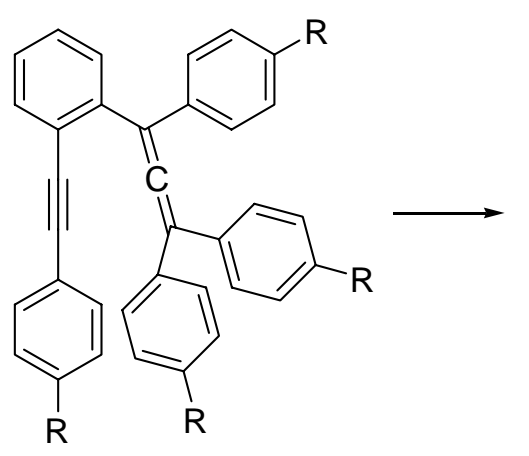

14a: $\mathrm{R}=\mathrm{H}$

14b: $\mathrm{R}=t-\mathrm{Bu}$

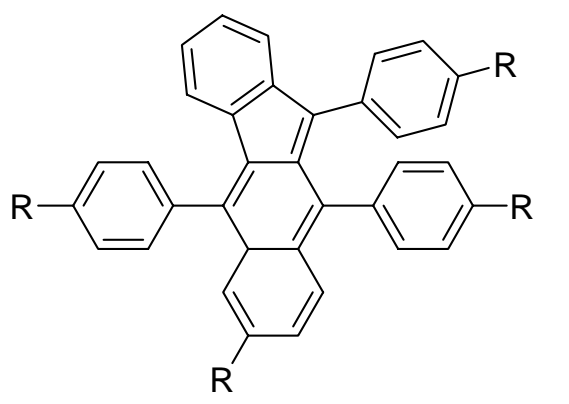

16a: $\mathrm{R}=\mathrm{H}$

16b: $\mathrm{R}=t-\mathrm{Bu}$

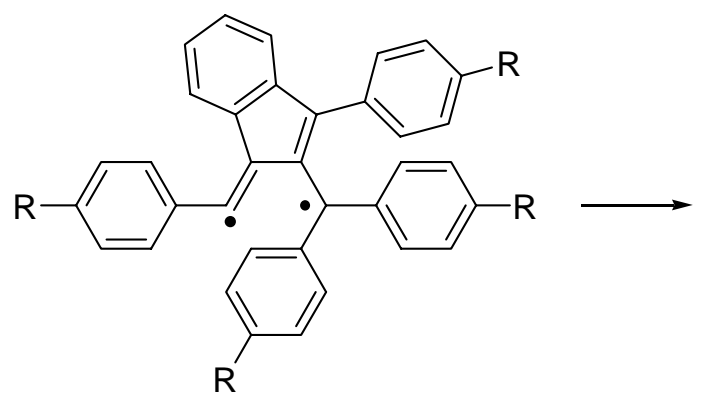

15a: $\mathrm{R}=\mathrm{H}$

15b: $R=t-B u$

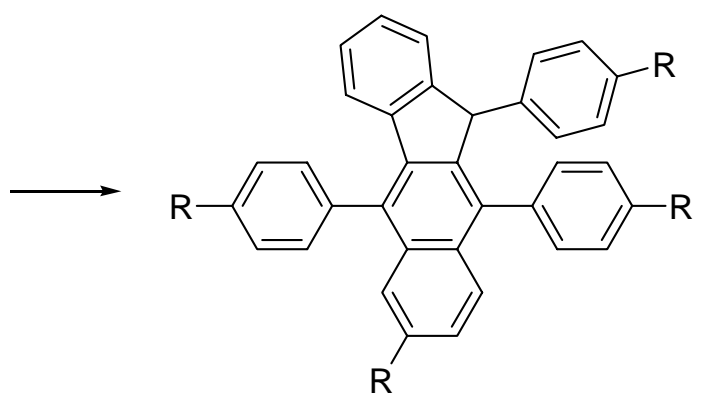

17a: $\mathrm{R}=\mathrm{H}, 50 \%$

17b: $\mathrm{R}=t-\mathrm{Bu}, 76 \%$

\section{Scheme 3}

Dr. Hai-Ren Zhang first reported the synthesis of 5,10-diphenyl-11Hbenzo[b]fluorene in 1999 and the synthesis relied on enyne-allene Schmittel cyclization (Scheme 4). ${ }^{10 \mathrm{c}, 10 \mathrm{f}}$ The synthetic sequence involved Horner olefination of aldehyde $\mathbf{1 8}$ with phosphinoxy carbanion in THF at $-78{ }^{\circ} \mathrm{C}$ to room temperature to produce benzoenyne-allenes 19, which then underwent a facile C2-C6 cyclization at room temperature to form the biradical $\mathbf{2 0}$. The subsequent intramolecular radical-radical coupling produced 21, leading to 
the 5,10-diphenyl-11H-benzo[b]fluorene 7 through tautomerization in $51 \%$ yield. There are ample precedents in the literature to support the formation of the formal Diels-Alder adduct 21 through a 2 steps C2-C6 cyclization involving a biradical intermediate 2 . $^{12}$

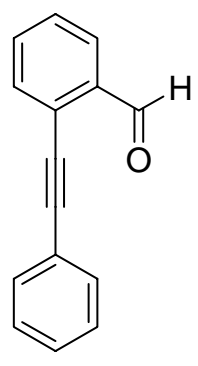

18

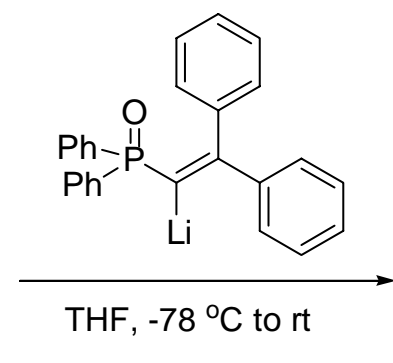

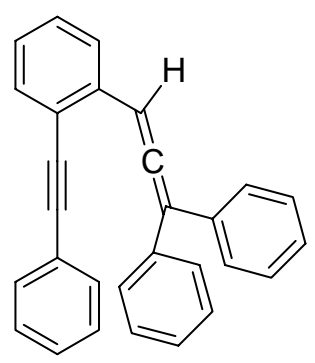

19

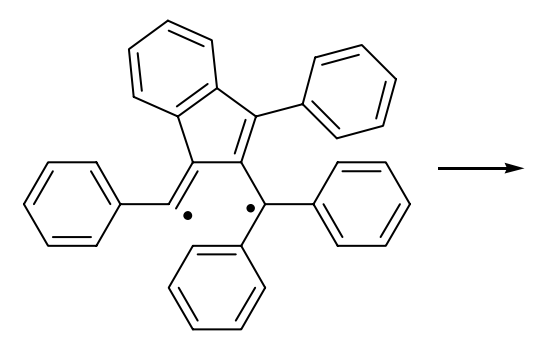

20

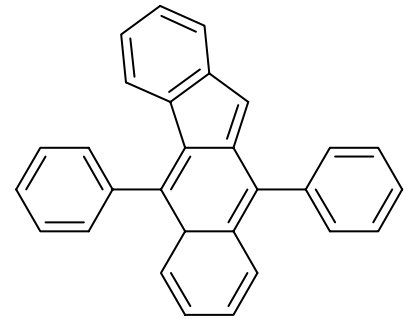

21

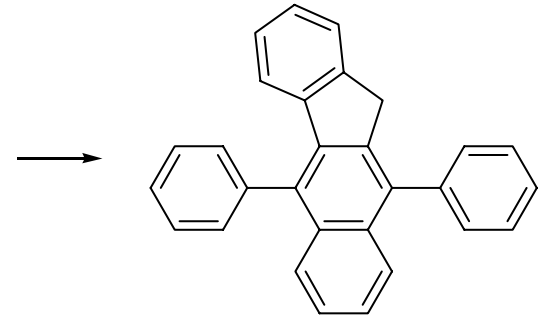

7: $51 \%$

Scheme 4

In 2001, Dr. Hongbin Li reported the synthesis of 5,10-diphenyl-11Hbenzo[b]fluoren-11-ol (Scheme 5). ${ }^{10 \mathrm{~d}}$ It was obtained from condensation of benzophenone (22) with the lithium acetylide 23, obtained by lithiation of 1(2-ethynylphenyl)-2-phenylethyne with $n$-butyllithium, followed by hydrolytic workup to furnish the propargylic alcohol 24. Treatment of $\mathbf{2 4}$ with thionyl chloride promoted a sequence of reactions with an initial 
formation of chlorosulfite 25 followed by an $\mathrm{S}_{\mathrm{N}} \mathrm{i}^{\prime}$ reaction ${ }^{14}$ to produce in situ the chlorinated benzoenyne-allene 26.

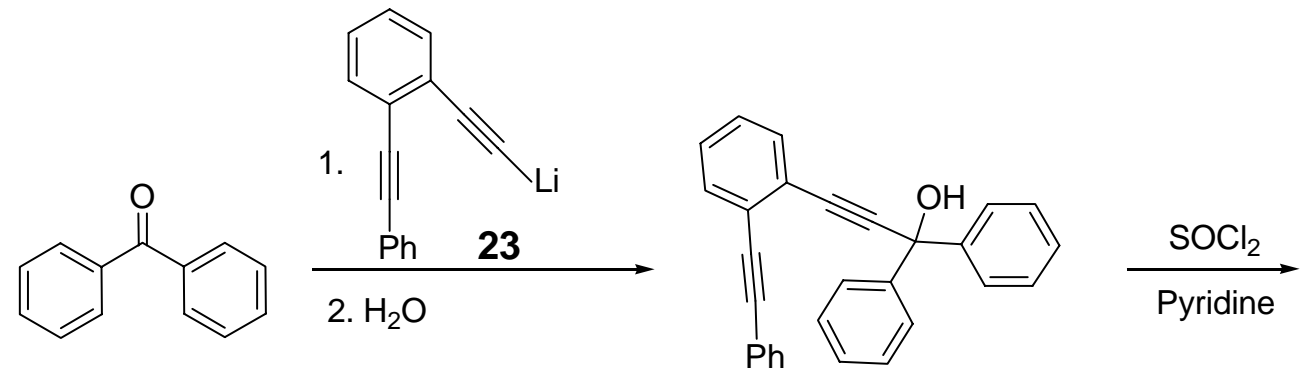

22

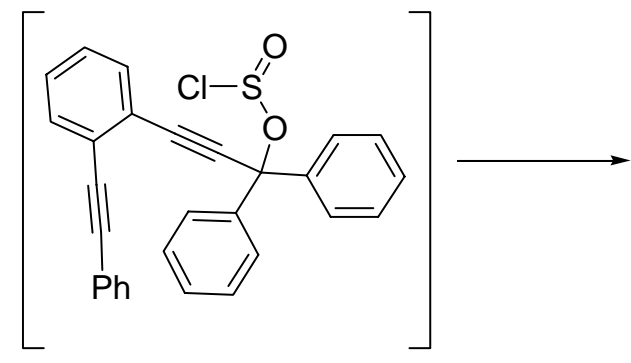

25<smiles>ClC1=C(C(c2ccccc2)c2ccccc2)C(=Cc2ccccc2)c2ccccc21</smiles>

27

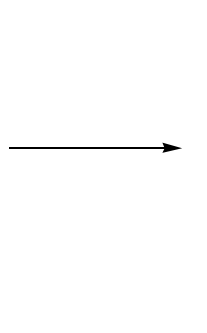

L<smiles>O[SiH3]O</smiles>

29

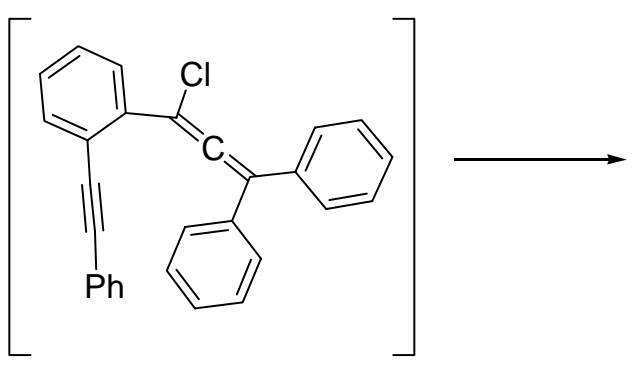

26
24<smiles>ClC1=C(c2ccccc2)C2=C(c3ccccc3)C(c3ccccc3)C3C=CC=CC3C=C12</smiles>

28<smiles></smiles>

30

Scheme 5 
A Schmittel (C2-C6) cyclization reaction generated the biradical 27, which in turn underwent a radical-radical coupling to afford the formal Diels-Alder adduct 28 and subsequently after tautomerization gave chloride 29. The chloride 29 was prone to hydrolysis and, on exposure to water/silica gel, the chloride 29 was converted to the 5,10-diphenyl-11H-benzo[b]fluoren-11-ol 30 in $85 \%$ overall yield from alcohol 24.

Dr. Hongbing Li also developed a new synthetic pathway for the synthesis of 10-(1,1-dimethylethyl)-5-phenyl-11H-benzo[b]fluorene 37 (Scheme 6). ${ }^{10 \mathrm{~d}}$ The synthetic sequence involved condensation of 2,2dimethylpropiophenone (31) with the lithium acetylide 23, obtained by lithiation of 1-(2-ethynylphenyl)-2-phenylethyne with $n$-butyllithium, followed by hydrolytic workup to furnish the propargylic alcohol 32 . Treatment of alcohol 32 with triethylsilane followed by trifluoroacetic acid ${ }^{15}$ produced hydrocarbon 33 in 96\% yield. Prototropic isomerization, promoted by potassium tert-butoxide in refluxing toluene, ${ }^{16}$ produced the benzoenyne-allene 34 in situ, which in turn underwent a formal $[4+2]$ cycloaddition reaction to furnish 36 and, after tautomerization, 10-(1,1dimethylethyl)-5-phenyl-11H-benzo[b]fluorene 37 in 90\% yield. 


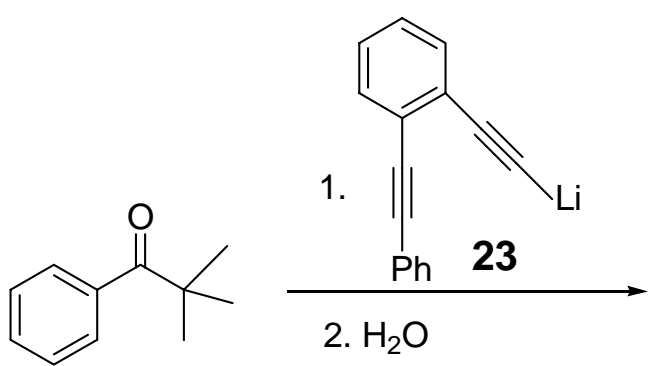

31

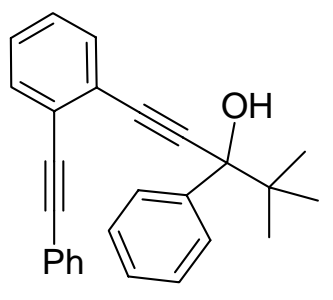

32<smiles>CCCCC(C)(C)OC(C)(C)C(C)(C)C(C)(C)C</smiles>

33

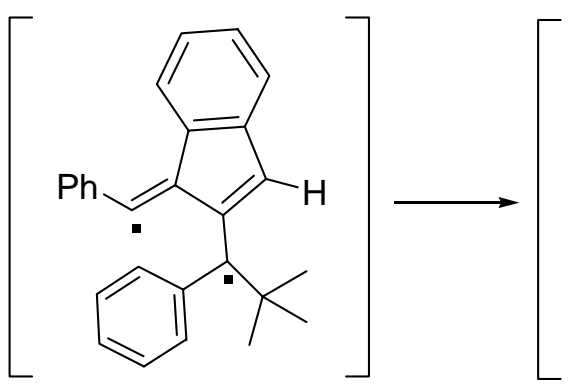

35

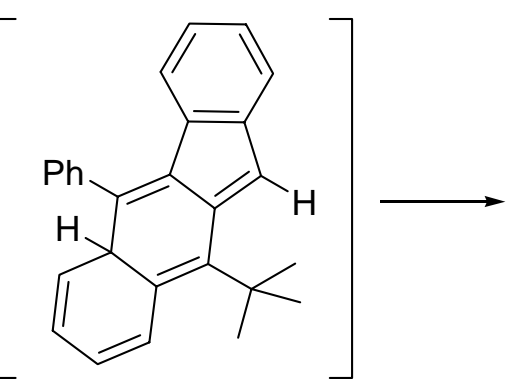

36<smiles>CC(C)(C)c1c2c(c(-c3ccccc3)c3ccccc13)-c1ccccc1C2</smiles>

37

\section{Scheme 6}

In 2003, Dr. Yonghong Yang studied the cyclization of diol 39 with two benzannulated enyne-allene units induced by the thionyl chloride (Scheme 7). ${ }^{17}$ The diol 39 was synthesized from condensation between diketone 38 and 2 equivalents of lithium acetylide 23. It was assumed that the Schmittel cyclization reaction of $\mathbf{3 9}$ would produce the desired 
hydrocarbon 41. Unexpectedly, cleaveage of the central benzene ring occurred during the course of cyclization, leading to the highly twisted $1,1^{\prime}-$ dialkyl-9,9'-bifluorenylidene $\mathbf{4 0}$.

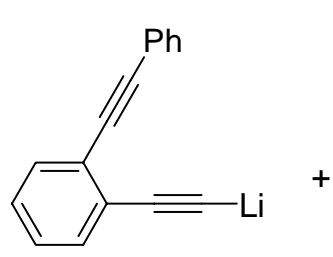

23<smiles>CCCc1c(CCC)c2c(=O)c3ccccc3c2c2c1c(=O)c1ccccc12</smiles>

38

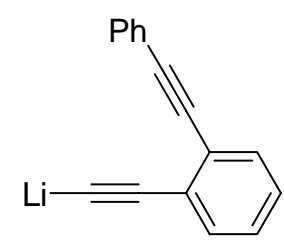

23

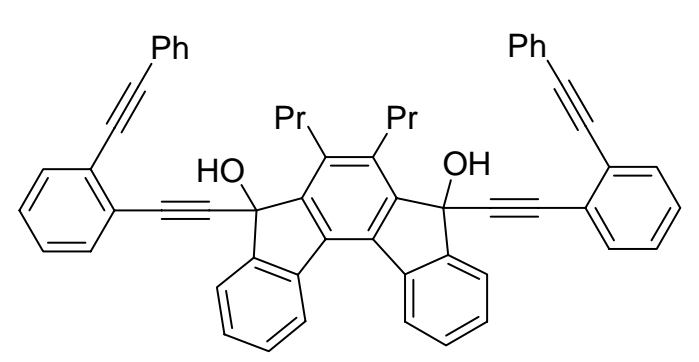

39

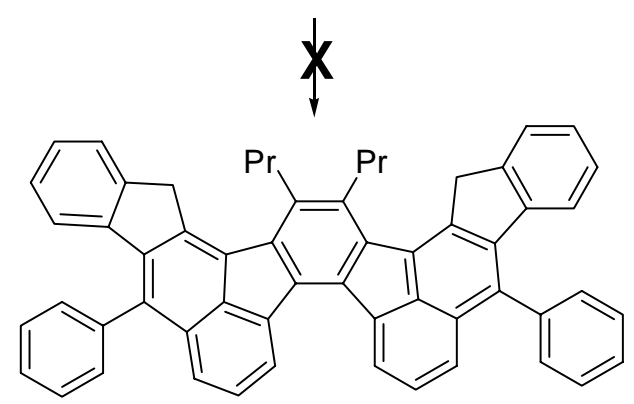

41

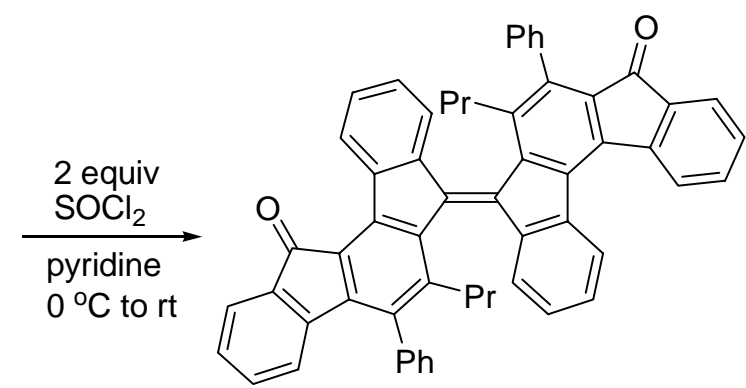

40

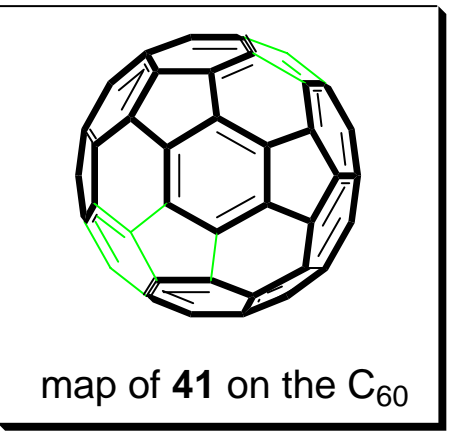

Scheme 7

It is worth noting that hydrocarbon $\mathbf{4 1}$ has a 52-carbon framework represented on the surface of $\mathrm{C}_{60}$ (Scheme 7) and may eventually lead to the formation of bowl-shaped polycyclic aromatic hydrocarbons (buckybowls). 
Recently, Daehwan Kim of our group reported the synthesis of bowlshaped polycyclic aromatic hydrocarbons 52 via palladium-catalyzed intramolecular arylation reactions (Scheme 8). ${ }^{18}$ In his reaction sequence the benzannulated enediyne 45 was obtained in good yield via a Sonogashira coupling between (2,6-dibromophenyl)ethyne 42 and (trimethylsilyl)ethyne 43 followed by desilylation. ${ }^{19}$ Condensation of 45 with pivalophenone produced enediynyl propargylic alcohol 46, which upon treatment with triethyl silane in the presence of trifluoroacetic acid afforded benzannulated endiyne 47. On exposure of $\mathbf{4 7}$ with $t$-BuOK in refluxing toluene for $12 \mathrm{~h}$ produced 5-(2,6-dibromophenyl)-10-(1,1-dimethylethyl)-11H-benzo[b] fluorene 51 in a single operation with good yield. Presumably, the transformation from $\mathbf{4 7}$ to 51 proceeded through an initial 1,3-prototropic rearrangement to form the corresponding benzannulated enyne-allen $\mathbf{4 8}$. The enyne-allen 48 underwent a Schemittel cyclization reaction to generate biradical 49 followed by an intramolecular radical-radical coupling to afford, in situ, 50. A second prototropic rearrangement to regain aromaticity then gave 51. Treatment of 51 with $10 \mathrm{~mol} \%$ of $\mathrm{Pd}\left(\mathrm{PPh}_{3}\right)_{2} \mathrm{Br}_{2}$ in the presence of DBU at $150{ }^{\circ} \mathrm{C}^{20}$ for $72 \mathrm{~h}$ furnished bulkybowl 52. 


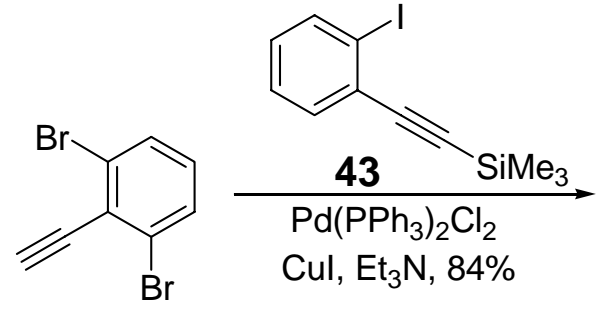

42

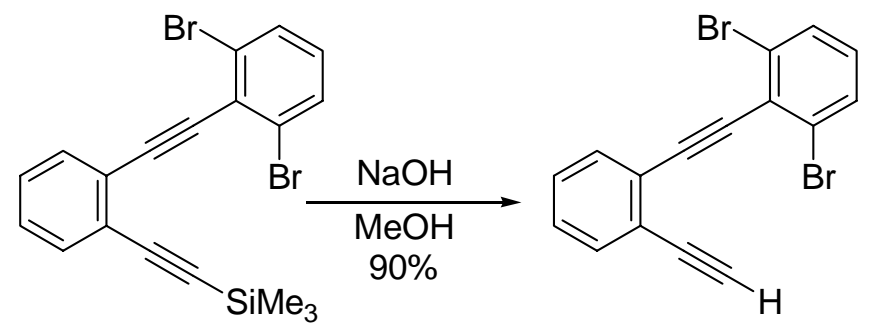

45

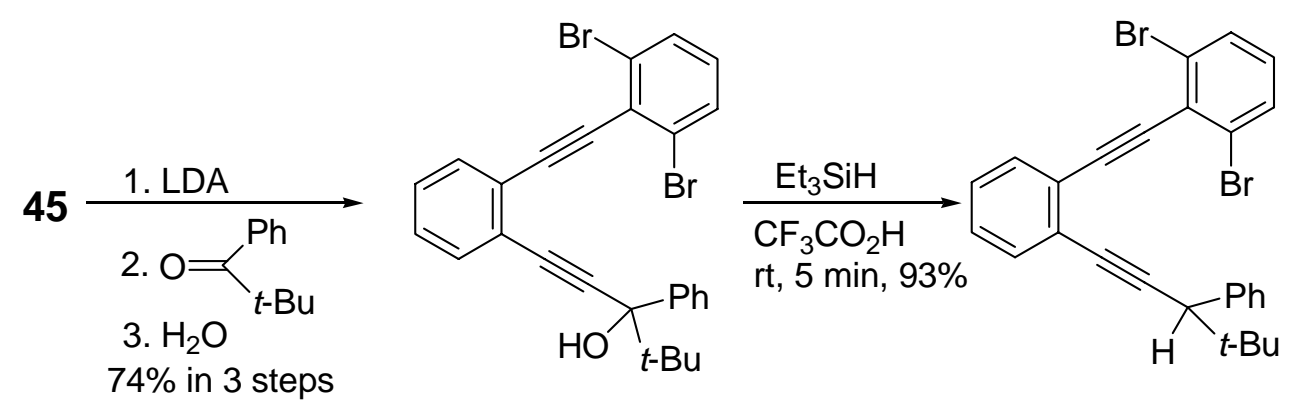

46

47

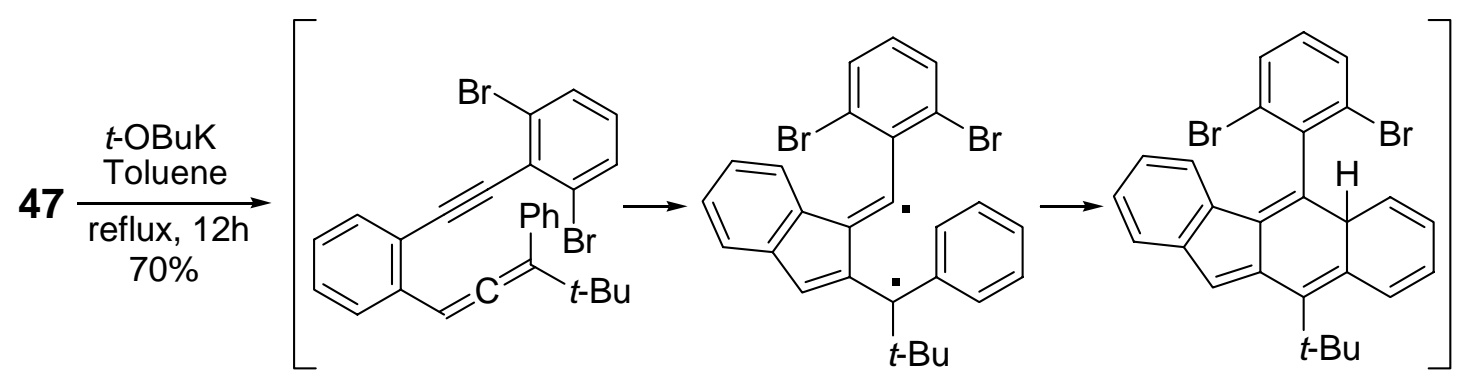

48

49

50<smiles>CC(C)(C)c1c2c(c(-c3c(Br)cccc3Br)c3ccccc13)-c1ccccc1C2</smiles>

51<smiles>CC(C)(C)c1c2c3c4c(cccc4c4cccc1c4=3)Cc1cccc3c1C=23</smiles>

52

Scheme 8 


\section{Results and Discussion}

With our ongoing interest in the synthesis of polycyclic aromatic hydrocarbons, we envisioned a retrosynthetic sequence outlined in Scheme 9 for the synthesis of polycyclic aromatic hydrocarbon 53. The polycyclic aromatic hydrocarbon 53 could be synthesized from alkyl iodide 54 via intramolecular alkylation. Alkyl iodide 54 could be achieved from deprotection of methyl ether $\mathbf{5 5}$ followed by iodination. The methyl ether 55 could be obtained from the propargylic alcohol $\mathbf{5 6}$ via reduction and cascade cyclization.

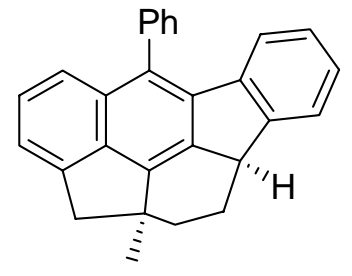

53

\section{$t$-BuOK}<smiles></smiles>

54
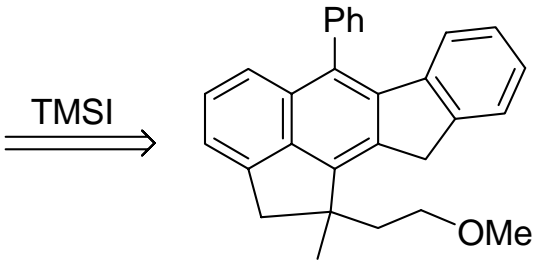

55<smiles>COCCC1(C)CC2=CC=CC3=C(c4ccccc4)C4=C(C(=C21)C3)c1ccccc1C4</smiles>

55<smiles>[C]C#Cc1ccccc1C#Cc1ccccc1</smiles>

23

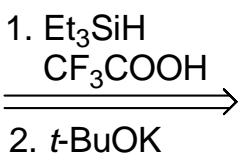

2. $t$-BuOK

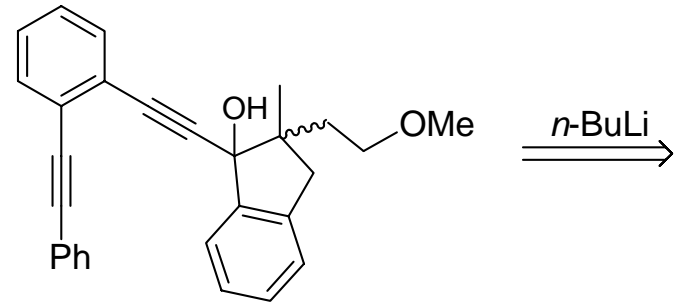

56<smiles>COCCC1(C)Cc2ccccc2C1=O</smiles>

57<smiles>COCCI</smiles>

58 59

Scheme 9: Retrosynthetic analysis 
The propargylic alcohol 56 could be synthesized from condensation of lithium acetylide 23 and the substituted indanone 57, which could be achieved from alkylation of indanone (58).

As outlined in Scheme 10, the alkyl iodide 59 was synthesized from 2-methoxy ethanol via mesylation using methanesulfonylchloride in dichloromethane and triethylamine followed by iodination with lithium iodide producing 59 in $70 \%$ yield over 2 steps. $^{21}$

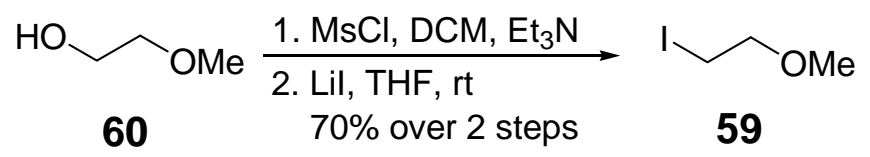<smiles>O=C1CCc2ccccc21</smiles>

58

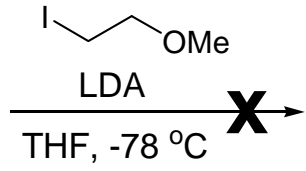

THF, $-78^{\circ} \mathrm{C} \times$<smiles>COCCC1Cc2ccccc2C1=O</smiles>

61<smiles>COCCC1CC(=O)c2ccc(CC(C)C)cc21</smiles>

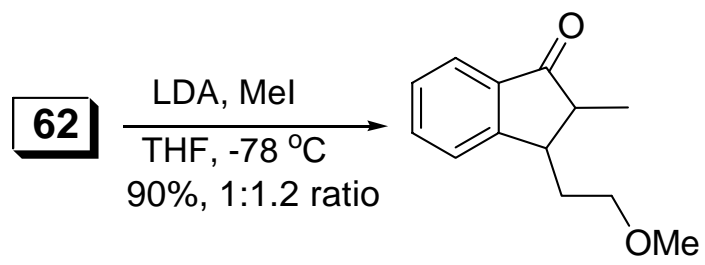

63

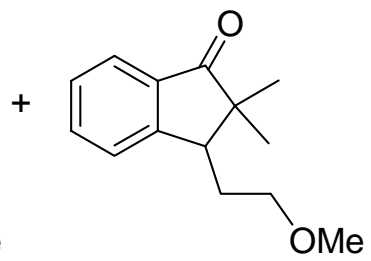

64

\section{Scheme 10}

Unexpectedly, the alkylation of indanone with lithium diisopropylamine 
(LDA)/2-methoxy-1-iodoethane yielded the $\beta$-alkylated product 62 instead of the desired $\alpha$-alkylated product 61 . This is presumably via the formation of dianion 58a. By proton NMR it was very difficult to distinguish the $\alpha$ alkylated or $\beta$-alkylated product $\mathbf{6 1 / 6 2}$. Then, we proceed for second alkylation by using LDA/methyl iodide giving mono and dimethylated product 63 and 64 in 90\% yield with 1:1.2 ratio. By proton NMR of 63, we concluded that the monomethylated product 63 was not our required product 57. Furthermore, NOESY spectrum of all three alkylated products 62,63 and 64 revealed that the first alkylation of indanone occurred at the $\beta$ position and the second methylation at $\alpha$-position of indanone (figure 3-5).

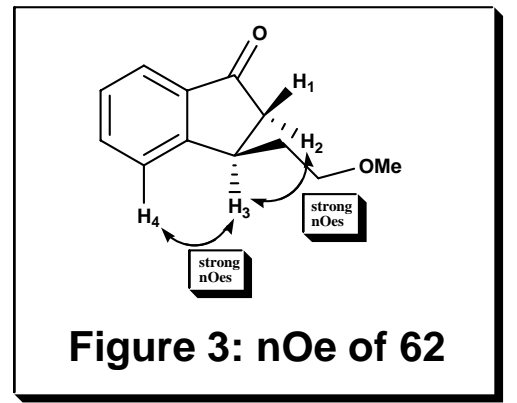

In the NOESY spectrum of 62 (figure 3 ), $\mathrm{H}_{3}$ proton at $3.51 \mathrm{ppm}$ shows strong nOes to $\mathrm{H}_{1}$ and $\mathrm{H}_{2}$ proton at 2.91 and $2.42 \mathrm{ppm}$ respectively. In addition, $\mathrm{H}_{3}$ proton also shows strong nOes to $\mathrm{H}_{4}$ proton at $7.50 \mathrm{ppm}$. But, there are no nOes between $\mathrm{H}_{1}$ and $\mathrm{H}_{4}$ or $\mathrm{H}_{2}$ and $\mathrm{H}_{4}$ proton. 


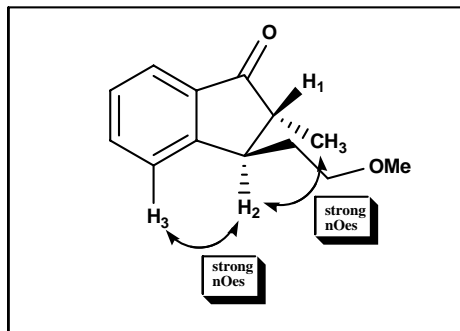

Figure 4: nOe of 63

Again, in the NOESY spectrum of 63 (figure 4), $\mathrm{H}_{2}$ proton at $3.08 \mathrm{ppm}$ shows strong nOes to alpha methyl protons at 1.33 and $\mathrm{H}_{3}$ proton at 7.50 ppm. In addition to that, when we irradiate the alpha methyl protons at 1.33 ppm shows strong nOes to $\mathrm{H}_{1}$ and $\mathrm{H}_{2}$ proton at 2.43 and $3.08 \mathrm{ppm}$ respectively. But, there are no nOes between $\mathrm{H}_{3}$ and alpha methyl protons.

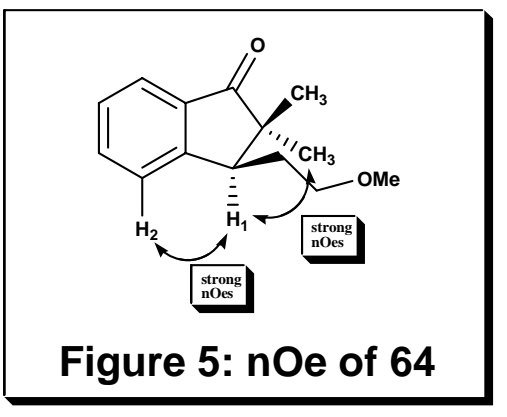

Similarly, in the NOESY spectrum of $\mathbf{6 4}$ (figure 5), $\mathrm{H}_{1}$ proton at 3.15 ppm shows strong nOes to alpha methyl protons at 1.23 and $1.13 \mathrm{ppm}$ respectively. In addition, $\mathrm{H}_{1}$ proton also shows strong nOes to $\mathrm{H}_{2}$ proton at $7.50 \mathrm{ppm}$. But, there are no nOes between $\mathrm{H}_{2}$ and alpha methyl protons. From above three experiments we confirmed, the 2-methoxyethyl group was at the beta position of indanone. 
Having difficulties in alkylation, we tried methylation of indanone first using LDA/MeI followed by the second alkylation using LDA/1-iodo-2methoxyethane (Scheme 11). That is to say, treatment of commercially available indanone with LDA/MeI in THF at $-78{ }^{\circ} \mathrm{C}$ gave monomethyl indanone 65 and dimethyl indanone 66 in 90\% yield with 1:1.2 ratio and separated by column chromatography. ${ }^{22}$ Unfortunately, the second alkylation failed to produce the desired product 57. Instead, we recovered the starting material methyl indanone 65. Auspiciously, the second alkylation underwent smoothly with LDA/allylbromide in THF at $-78{ }^{\circ} \mathrm{C}$ to afford the substituted indanone $\mathbf{6 7}$ in $85 \%$ yield.
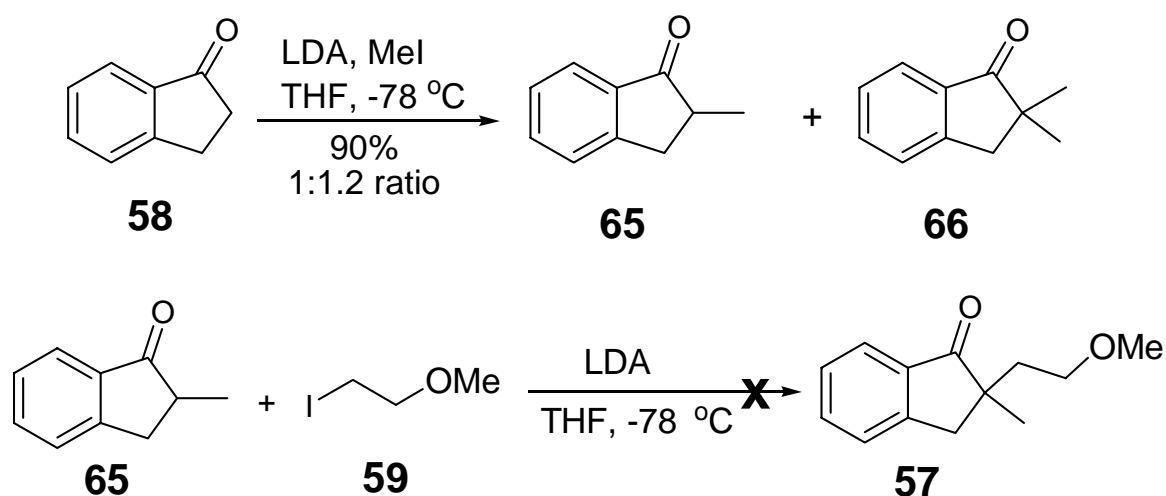

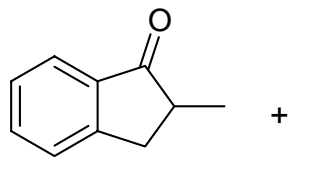

65

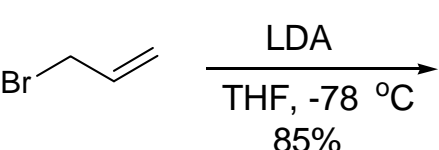

$85 \%$

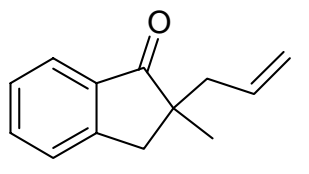

67

Scheme 11

Condensation of 67 with the lithium acetylide 23, obtained by lithiation of 1-(2-ethynylphenyl)-2-phenylethyne $\mathbf{6 8}^{23}$ with $n$-butyllithium, 
followed by hydrolytic workup furnished the propargylic alcohol 69 in $75 \%$ yield with a 1:1 diastereomeric ratio (Scheme 12). Reduction of propargylic alcohol 69 with triethylsilane followed by trifluoroacetic acid ${ }^{15}$ produced hydrocarbon $\mathbf{7 0}$ in $80 \%$ yield.

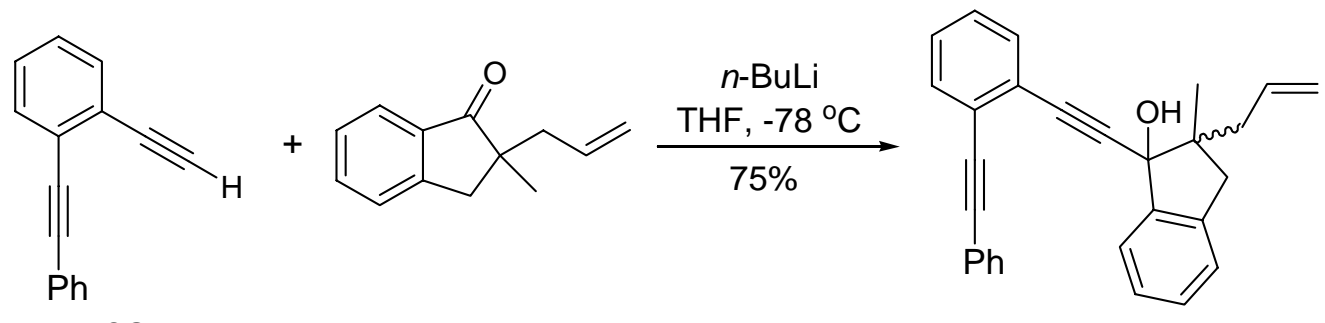

68

67

69

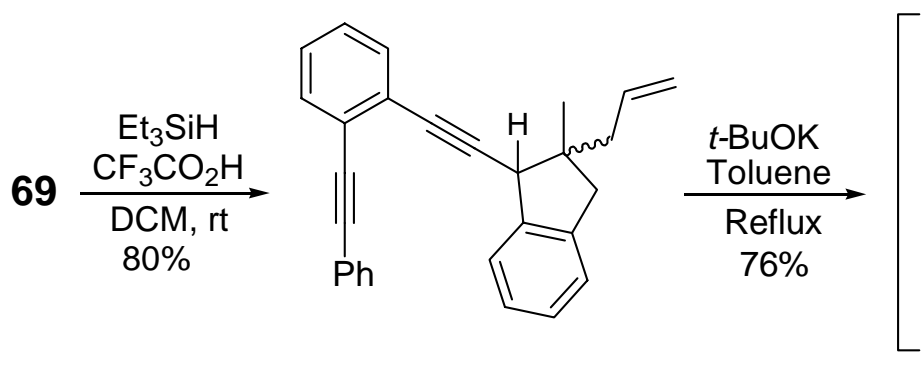

70

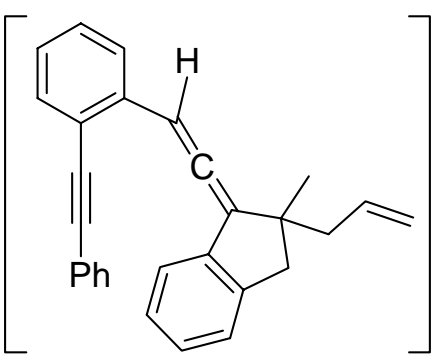

71

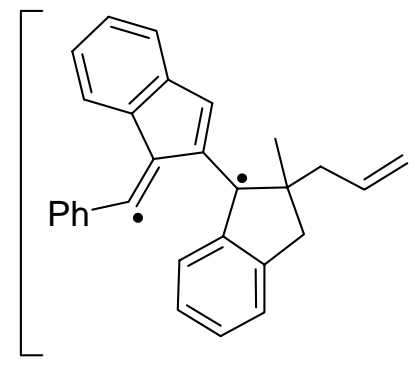

72

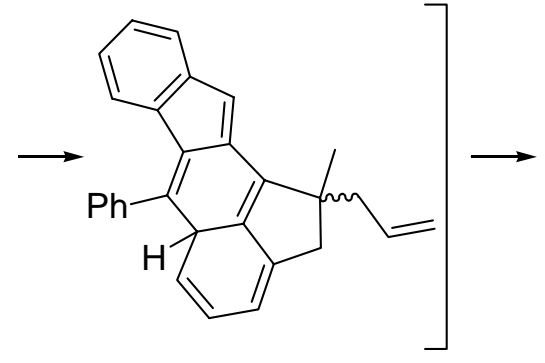

73

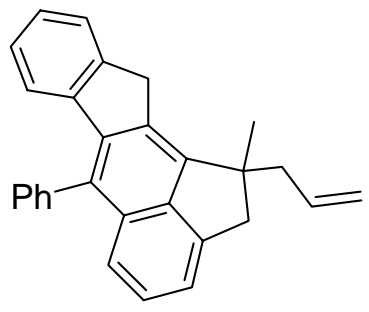

74

Scheme 12

Treatment of $\mathbf{7 0}$ with potassium $t$-butoxide under refluxing toluene produced alkene $\mathbf{7 4}$ in a single operation. ${ }^{16}$ The transformation from $\mathbf{7 0}$ to $\mathbf{7 4}$ presumably involved prototropic acetylene to allene rearrangements of the 
internal acetylenic moieties followed by formal intramolecular Diels-Alder reaction and subsequent prototropic rearrangement of the resulting Diels-Alder adduct 73. Hydroboration of alkene $\mathbf{7 4}$ with disiamylborane followed by iodination in the presence of sodium hydroxide afforded alkyl iodide 75 in $65 \%$ yield (Scheme 13). ${ }^{24}$ Treatment of alkyl iodide 75 with potassium $t$-butoxide in THF at $40{ }^{\circ} \mathrm{C}$ furnished the polycyclic aromatic hydrocarbon 76 in $60 \%$ yield.

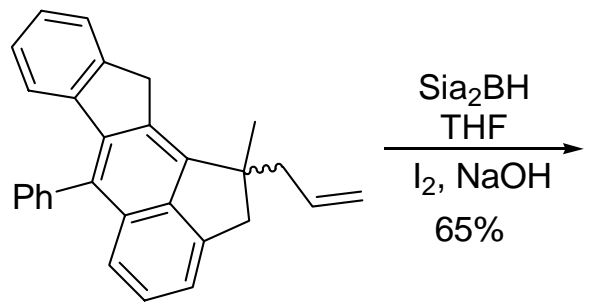

74

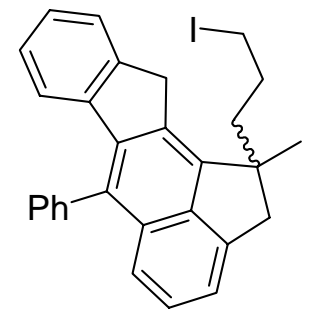

75

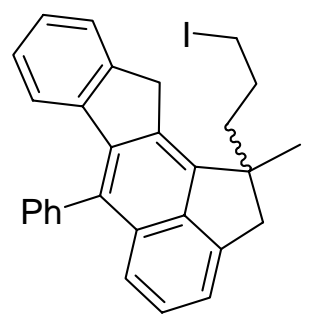

75

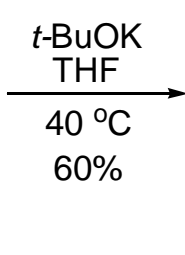

Scheme 13

The structure of 76 was confirmed by ${ }^{1} \mathrm{HNMR},{ }^{13} \mathrm{CNMR}$ and supported by CIHRMS which showed $[\mathrm{M}+\mathrm{H}]^{+}$peak at $\mathrm{m} / z$ 373.1951. The stereochemistry was confirmed by NOESY experiments of $\mathbf{7 6}$ (figure 6). 


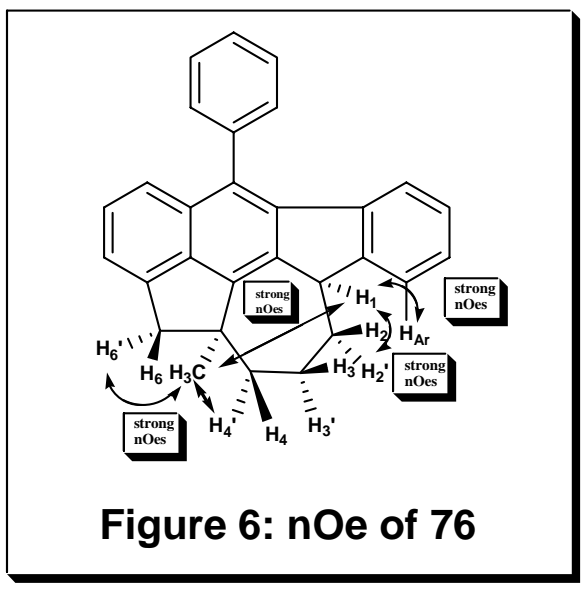

In the NOESY spectrum of $\mathbf{7 6}$ (figure 6), $\mathrm{H}_{1}$ proton at $4.20 \mathrm{ppm}$ shows strong nOes to $\mathrm{H}_{2}{ }^{\prime}$ proton at $2.57 \mathrm{ppm}$ and $\mathrm{H}_{\text {Ar }}$ proton at $7.42 \mathrm{ppm}$. In addition, $\mathrm{H}_{1}$ proton also shows strong nOes to $\mathrm{CH}_{3}$ proton at $1.60 \mathrm{ppm}$ and $\mathrm{H}_{3}{ }^{\prime}$ protons at $2.42 \mathrm{ppm}$. Similarly, $\mathrm{CH}_{3}$ proton at $1.60 \mathrm{ppm}$ shows strong nOes to $\mathrm{H}_{1}$ proton, $\mathrm{H}_{6}{ }^{\prime}$ protons at $3.34 \mathrm{ppm}$ and $\mathrm{H}_{4}{ }^{\prime}$ protons at $2.42 \mathrm{ppm}$. Therefore, the angular $\mathrm{CH}_{3}$ group is cis to $\mathrm{H}_{1}$.

\section{Conclusions}

A simple and efficient pathway employing Schmittel cyclization reaction to synthesize novel polycyclic aromatic hydrocarbon 76, having six fused rings was successfully developed. Using different combinations of benzoenediynes and substituted indanones for condensation, it is possible that a variety of other polycyclic aromatic hydrocarbons could likewise be synthesized. 


\section{Part II}

\section{Experimental Section}

General Methods and Materials. ${ }^{1} \mathrm{H}$ and ${ }^{13} \mathrm{C}$ NMR spectra were recorded on Varian VXR-600 (600 MHz) spectrometers. Chemical shifts are reported relative to $\mathrm{CDCl}_{3}(\delta 7.26 \mathrm{ppm})$ for ${ }^{1} \mathrm{H}$ and $\mathrm{CDCl}_{3}(\delta 77.0 \mathrm{ppm})$ for ${ }^{13} \mathrm{C}$. Infrared (IR) spectra were obtained on a Prospect MIDAC FT-IR spectrometer. Melting points were determined with Electrothermal MelTemp apparatus and are uncorrected. Flash column chromatography was performed on ICN reagent 60 (60-200 mesh) silica gel. Analytical thin-layer chromatography was performed with precoated glass-backed plates (Whatman $\mathrm{K} 6 \mathrm{~F} 60 \AA, \mathrm{F}_{254}$ ) and visualized by UV-lamp at $254 \mathrm{~nm} . R_{f}$ values are obtained by elution in the stated solvent ratios (v/v). Diethylether, THF, methylene chloride and triethylamine were dried by passing through activated alumina column with argon gas pressure. Commercial reagents were used without purification unless otherwise noted. Air and/or moisturesensitive reactions were carried out under an atmosphere of argon/nitrogen using oven-dried glassware and standard syringe/septa techniques. 
1-Iodo-2-methoxyethane (59). ${ }^{21}$ A solution of methanesulfonyl chloride (900 mg, $7.8 \mathrm{mmol})$ in dichloromethane $(50 \mathrm{~mL})$ was added over $10 \mathrm{~min}$ to a solution of 2-methoxy ethanol (500 mg, $6.5 \mathrm{mmol})$ and $\mathrm{Et}_{3} \mathrm{~N}(1.052 \mathrm{~g}, 10.4$ mmol) in dichloromethane $(50 \mathrm{~mL})$. The reaction mixture was stirred for 1 hr and was quenched with aq satd. $\mathrm{NaHCO}_{3}$ and organic phase was dried over $\mathrm{Na}_{2} \mathrm{SO}_{4}$ and evaporated. The crude mesylate was dissolved in THF (80 $\mathrm{mL})$, Lithium iodide (2.6 $\mathrm{g}, 19.5 \mathrm{mmol})$ was added and the resulting mixture was stirred for $4 \mathrm{hr}$ at room temperature. After evaporation of all the volatile components, the residue was suspended in hexane, and the suspension was vigorously stirred for $5 \mathrm{~min}$. The crude product was filtered off through a short pad of silica, and the filtrate was evaporated. The residue was dried in vacuo to give 1-Iodo-2-methoxyethane (59) as sticky oil in $80 \%$ yield: ${ }^{1} \mathrm{H}$ $\operatorname{NMR}\left(600 \mathrm{MHz}, \mathrm{CDCl}_{3}\right) \delta 3.66(\mathrm{t}, J=6.6 \mathrm{~Hz}, 2 \mathrm{H}), 3.40(\mathrm{~s}, 3 \mathrm{H}), 3.26(\mathrm{t}, J=$ $6.6 \mathrm{~Hz}, 2 \mathrm{H}) ;{ }^{13} \mathrm{C} \mathrm{NMR}\left(150 \mathrm{MHz}, \mathrm{CDCl}_{3}\right) \delta 73.1,58.4,2.6$.

2,3-Dihydro-3-(2-methoxyethyl)inden-1-one (62). 1-Indanone (200 mg, $1.5 \mathrm{mmol}$ ) was dissolved in $100 \mathrm{~mL}$ of THF under nitrogen, to which was added $1 \mathrm{M}$ solution of lithium diisopropylammine $(1.8 \mathrm{~mL}, 1.8 \mathrm{mmol})$ at -78 ${ }^{\circ} \mathrm{C}$ and stirred for $30 \mathrm{~min}$ and lastly 1-Iodo-2-methoxyethane (59) (0.36 g, $1.95 \mathrm{mmol}$ ) was then added via syringe. The reaction was allowed to stir for $2 \mathrm{hr}$ at room temperature, and then the reaction was quenched by adding 100 
$\mathrm{mL}$ of satd. $\mathrm{NH}_{4} \mathrm{Cl}$ and $200 \mathrm{~mL}$ of diethyl ether. The organic layer was separated, and the aqueous layer was back extracted with diethyl ether ( $3 \mathrm{x}$ $100 \mathrm{~mL}$ ). The organic layers were combined and washed with $200 \mathrm{~mL}$ of brine, dried using $\mathrm{Na}_{2} \mathrm{SO}_{4}$, and the solvent was removed under reduced pressure. Crude product was purified by silica gel chromatography with $5 \%$ EtOAc/hexane to afford pure 2,3-dihydro-2-(2-methoxyethyl)inden-1-one (62, $185 \mathrm{mg}, 65 \%$ yield $): \mathrm{R}_{f}(30 \%$ EtOAc/Hexanes $)=0.24 ;{ }^{1} \mathrm{H}$ NMR $(600$ $\left.\mathrm{MHz}, \mathrm{CDCl}_{3}\right) \delta 7.75(\mathrm{~d}, J=7.8,1 \mathrm{H}), 7.60(\mathrm{dd}, J=8.4,7.8 \mathrm{~Hz}, 1 \mathrm{H}), 7.51(\mathrm{~d}$, $J=7.8 \mathrm{~Hz}, 1 \mathrm{H}), 7.38(\mathrm{dd}, J=8.4,7.8,1 \mathrm{H}), 3.54-3.50(\mathrm{~m}, 2 \mathrm{H}), 3.48-3.44$ (m, 1H), $3.36(\mathrm{~s}, 3 \mathrm{H}), 2.89(\mathrm{dd}, J=18.6,7.8 \mathrm{~Hz}, 1 \mathrm{H}), 2.45(\mathrm{dd}, J=18.6,3.6$ $\mathrm{Hz}, 1 \mathrm{H}), 2.25-2.20(\mathrm{~m}, 1 \mathrm{H}), 1.75-1.70(\mathrm{~m}, 1 \mathrm{H}) ;{ }^{13} \mathrm{C} \mathrm{NMR}\left(150 \mathrm{MHz}, \mathrm{CDCl}_{3}\right)$ $\delta 206.1,158.4,136.7,134.6,127.5,125.6,123.6,70.8,58.7,43.1,35.9,35.3$.

\section{2,3-Dihydro-2,2-dimethyl-3-(2-methoxyethyl)inden-1-one/2,3-Dihydro-}

\section{2-methyl-3-(2-methoxyethyl)inden-1-one $\quad \mathbf{( 6 4 / 6 3 ) . \quad 2 , 3 - d i h y d r o - 3 - ( 2 - ~}$} methoxyethyl) inden-1-one 62 (100 mg, $0.52 \mathrm{mmol})$ was dissolved in $25 \mathrm{~mL}$ of THF and cooled to $-78{ }^{\circ} \mathrm{C}$. To the solution was added $1 \mathrm{M}$ solution of lithium diisopropylammine $(0.78 \mathrm{~mL}, 0.78 \mathrm{mmol})$ via cannula under nitrogen atmosphere and stirred for $30 \mathrm{~min}$. Methyl iodide $(0.04 \mathrm{~mL}, 0.78$ mmol) was added and allowed to stir at room temperature for $2 \mathrm{hr}$ the reaction was then quenched by adding $100 \mathrm{~mL}$ saturated $\mathrm{NH}_{4} \mathrm{Cl}$ and $100 \mathrm{~mL}$ 
of diethyl ether. The organic layer was separated and the aqueous layer was back extracted with diethyl ether $(3 \times 50 \mathrm{~mL})$. The organic layers were combined and washed with $100 \mathrm{~mL}$ of brine, dried over $\mathrm{Na}_{2} \mathrm{SO}_{4}$, and the solvent removed under reduced pressure. Crude product was purified by silica gel chromatography with $10 \%$ EtOAc/hexane to give pure 2,3dihydro-2,2-dimethyl-3-(2-methoxyethyl)inden-1-one/2,3-dihydro-2-methyl3-(2-methoxyethyl)inden-1-one (64/63) in 50\% and $40 \%$ yield respectively. 2,3-dihydro-2,2-dimethyl-3-(2-methoxyethyl)inden-1-one (64): $\mathrm{R}_{f} \quad(30 \%$ EtOAc/Hexanes $)=0.35 ;{ }^{1} \mathrm{H}$ NMR $\left(600 \mathrm{MHz}, \mathrm{CDCl}_{3}\right) \delta 7.75(\mathrm{~d}, J=7.8,1 \mathrm{H})$, $7.60(\mathrm{dd}, J=8.4,7.8 \mathrm{~Hz}, 1 \mathrm{H}), 7.50(\mathrm{~d}, J=7.8 \mathrm{~Hz}, 1 \mathrm{H}), 7.38(\mathrm{dd}, J=8.4$, 7.8, 1H), 3.59-3.53 (m, 2H), $3.40(\mathrm{~s}, 3 \mathrm{H}), 3.15(\mathrm{dd}, J=7.8,7.2 \mathrm{~Hz}, 1 \mathrm{H})$, 2.06-2.00 (m, 1H), 1.94-1.89 (m, 1H), $1.23(\mathrm{~s}, 3 \mathrm{H}), 1.13(\mathrm{~s}, 3 \mathrm{H}) ;{ }^{13} \mathrm{C} \mathrm{NMR}$ $\left(150 \mathrm{MHz}, \mathrm{CDCl}_{3}\right) \delta 210.8,155.8,134.6,134.5,127.5,125.7,124.2,71.1$ $58.7,49.7,46.8,31.1,25.8,20.6$.

2,3-dihydro-2-methyl-3-(2-methoxyethyl)inden-1-one $\quad(63): \quad \mathrm{R}_{f} \quad(30 \%$ EtOAc/Hexanes $)=0.41 ;{ }^{1} \mathrm{H}$ NMR $\left(600 \mathrm{MHz}, \mathrm{CDCl}_{3}\right) \delta 7.75(\mathrm{~d}, J=7.8,1 \mathrm{H})$, $7.61(\mathrm{dd}, J=8.4,7.8 \mathrm{~Hz}, 1 \mathrm{H}), 7.50(\mathrm{~d}, J=7.8 \mathrm{~Hz}, 1 \mathrm{H}), 7.39(\mathrm{dd}, J=8.4$, $7.8,1 \mathrm{H}), \quad 3.59-3.50(\mathrm{~m}, 2 \mathrm{H}), 3.37(\mathrm{~s}, 3 \mathrm{H}), 3.08(\mathrm{td}, J=8.4,2.4 \mathrm{~Hz}, 1 \mathrm{H})$, $2.42(\mathrm{qd}, J=7.8,2.4 \mathrm{~Hz}, 1 \mathrm{H}), 2.31-2.25(\mathrm{~m}, 1 \mathrm{H}), 1.82-1.77(\mathrm{~m}, 1 \mathrm{H}), 1.32(\mathrm{~d}$, $J=7.8 \mathrm{~Hz}, 3 \mathrm{H}) ;{ }^{13} \mathrm{C} \mathrm{NMR}\left(150 \mathrm{MHz}, \mathrm{CDCl}_{3}\right) \delta 208.6,156.8,135.9,134.8$, 
$127.6,125.4,123.8,70.7,58.7,48.9,44.1,35.3,16.1$.

2,3-Dihydro-2-methyl-2-(2-propenyl) inden-1-one (67): 2,3-Dihydro-2methylinden- 1-one (65) (800 mg, $5.5 \mathrm{mmol})$ was dissolved in $250 \mathrm{~mL}$ of THF and cooled to $-78{ }^{\circ} \mathrm{C}$. To the solution was added $1 \mathrm{M}$ solution of lithium diisopropylammine $(6.1 \mathrm{~mL}, 6.1 \mathrm{mmol})$ via cannula under a nitrogen atmosphere. The reaction mixture was stirred for $30 \mathrm{~min}$ before allyl bromide $(0.53 \mathrm{~mL}, 6.1 \mathrm{mmol})$ was added. After $2 \mathrm{~h}$ room temperature, the reaction was quenched by adding $100 \mathrm{~mL}$ of saturated $\mathrm{NH}_{4} \mathrm{Cl}$ and $200 \mathrm{~mL}$ of diethyl ether. The organic layer was separated and aqueous layer was back extracted with diethyl ether $(3 \times 150 \mathrm{~mL})$. The organic layers were combined and washed with $300 \mathrm{~mL}$ of brine, dried over $\mathrm{Na}_{2} \mathrm{SO}_{4}$, and the solvent was removed under reduced pressure. The crude product was purified by silica gel chromatography with $10 \%$ EtOAc/hexane to give pure 67 (870 $\mathrm{mg}, 85 \%$ yield): $\mathrm{R}_{f}(30 \%$ EtOAc/Hexanes $)=0.86$; IR (thin film, $\left.\mathrm{cm}^{-1}\right) 2923,2852,1742,1455,1436,1346,1114,1027,754 ;{ }^{1} \mathrm{H}$ NMR (600 $\left.\mathrm{MHz}, \mathrm{CDCl}_{3}\right) \delta$ 7.76-7.74 (m, 1H), 7.60-7.57 (m, 1H), 7.43-7.41 (m, 1H), 7.38-7.35 (m, 1H), 5.69-5.62 (m, 1H), 5.09-5.05 (m, 1H), 5.02-5.00 (m, 1H), $3.18(\mathrm{~d}, J=16.8 \mathrm{~Hz}, 1 \mathrm{H}), 2.85(\mathrm{~d}, J=16.8 \mathrm{~Hz}, 1 \mathrm{H}), 2.40-2.37(\mathrm{~m}, 1 \mathrm{H})$, 2.32-2.28 (m, 1H), $1.22(\mathrm{~s}, 3 \mathrm{H}) ;{ }^{13} \mathrm{C} \mathrm{NMR}\left(150 \mathrm{MHz}, \mathrm{CDCl}_{3}\right) \delta$ 210.7, 152.5, $135.9,134.8,133.8,127.4,126.5,124.2,118.3,48.8,42.5,39.4,23.7$. 
Propargylic Alcohol 69. To 1-(2-ethynylphenyl)-2-phenylethyne (68, 600 $\mathrm{mg}, 2.96 \mathrm{mmol})$ in $100 \mathrm{~mL}$ of THF under a nitrogen atmosphere at $-78{ }^{\circ} \mathrm{C}$ was added a $1.6 \mathrm{M}$ solution of $n$-butyllithium $(2.0 \mathrm{~mL}, 3.25 \mathrm{mmol})$ in hexanes. After $30 \mathrm{~min}$ of stirring, a solution of $\mathbf{6 7}(610 \mathrm{mg}, 3.25 \mathrm{mmol})$ in $50 \mathrm{~mL}$ of THF was charged via cannula, and the reaction mixture was allowed to warm at room temperature. After an additional $2 \mathrm{hr}$, the reaction mixture was quenced with $50 \mathrm{~mL}$ of satd. $\mathrm{NH}_{4} \mathrm{Cl}$, and the reaction mixture was extracted with diethyl ether $(3 \times 100 \mathrm{~mL})$. The organic layers were combined, washed with brine, dried over $\mathrm{Na}_{2} \mathrm{SO}_{4}$, and concentrated. Purification using silica gel chromatography (5\% EtOAc/hexane) provided propargylic alcohol $69(810 \mathrm{mg}, 2.0 \mathrm{mmol})$ in $70 \%$ yield as a $1: 1$ diastereomeric mixture: $\mathrm{R}_{f}(30 \%$ EtOAc/Hexanes $)=0.59$; IR (thin film, $\mathrm{cm}^{-}$ 1) $3447,3465,2971,2930,1736,1638,1598,1494,994,913,755 ;{ }^{1} \mathrm{H}$ NMR $\left(600 \mathrm{MHz}, \mathrm{CDCl}_{3}, 1: 1\right.$ diastereomeric mixture ) $\delta 7.67$ and 7.61 (two doublets, $J=7.8 \mathrm{~Hz}, J=7.2 \mathrm{~Hz}, 1 \mathrm{H}, 1: 1$ ratio), 7.55-7.50 (m, 2H), 7.43-7.41 (m, 2H), 7.33-7.22 (m, 6H), 7.18-7.10 (m, 2H), 6.04 and 5.82 (two multipletes, $1 \mathrm{H}, 1: 1$ ratio), 5.12-5.06 (m, 1H), 4.96-4.87 (m, 1H), 3.10 (d, $J$ $=15.6 \mathrm{~Hz}, 1 \mathrm{H}$ ), $2.78(\mathrm{~d}, J=15.6 \mathrm{~Hz}, 1 \mathrm{H}), 2.59$ and 2.56 (two doublets, $J=$ $7.2 \mathrm{~Hz}, J=7.2 \mathrm{~Hz}, 1 \mathrm{H}, 1: 1 \mathrm{ratio}$ ), 2.24-2.19 (m, 2H), 1.26 and 1.21 (two singlets, $3 \mathrm{H}, 1: 1$ ratio); ${ }^{13} \mathrm{C}$ NMR $\left(150 \mathrm{MHz}, \mathrm{CDCl}_{3}, 1: 1\right.$ diastereomeric 
mixture) $\delta 145.8,142.4,135.9,132.4,132.2(2 \mathrm{C}), 131.9,129.1,128.6,128.4$ (2C), 128.3, 128.1, $127.1(2 \mathrm{C}), 126.1,125.3,124.3,123.2,117.8,93.5,93.1$, $88.3,86.6,82.1,52.4,43.0,41.2,29.9$.

Diacetylenic Hydrocarbon 70. To a mixture of propargylic alcohol 69 (700 $\mathrm{mg}, 1.8 \mathrm{mmol})$ and triethylsilane $(520 \mathrm{mg}, 4.5 \mathrm{mmol})$ in $80 \mathrm{~mL}$ of dichloromethane was added trifluoroacetic acid $(820 \mathrm{mg}, 7.2 \mathrm{mmol})$. After $10 \mathrm{~min}$ of stirring at room temperature, sodium carbonate $(760 \mathrm{mg}, 7.2$ mmol) was added followed by $20 \mathrm{~mL}$ of water and $70 \mathrm{~mL}$ of diethyl ether. The organic layer was separated, washed with brine and water, dried over $\mathrm{Na}_{2} \mathrm{SO}_{4}$, and concentrated. Flash column chromatography (5\% EtOAc /hexane) provided diacetylenic hydocarbon $70(0.50 \mathrm{~g}, 1.3 \mathrm{mmol}, 75 \%)$ as a 1:1 mixture of diasteromers: $R_{f}(30 \%$ EtOAc/Hexanes $)=0.65$; IR $($ thin film, $\left.\mathrm{cm}^{-1}\right) 2985,1737,1373,1234,1043,938,847 ;{ }^{1} \mathrm{H}$ NMR $\left(600 \mathrm{MHz}, \mathrm{CDCl}_{3}\right.$, $1: 1 \mathrm{dr}) \delta$ 7.55-7.46 (m, 3H), 7.43-7.41 (m, 2H), 7.32-7.26 (m, 5H), 7.18-7.14 $(\mathrm{m}, 2 \mathrm{H}), 7.11-7.08(\mathrm{~m}, 1 \mathrm{H}), 5.95$ and 5.78 (two multipletes, $1 \mathrm{H}, 1: 1$ ratio), $5.09(\mathrm{~m}, 1 \mathrm{H}), 4.93$ and 4.86 (two multipletes, $1 \mathrm{H}, 1: 1$ ratio), 4.15 and 4.10 (two singlets, $1 \mathrm{H}, 1: 1$ ratio), 2.96 and 2.91 (two doublets, $J=15.6 \mathrm{~Hz}, J=$ $15 \mathrm{~Hz}, 1 \mathrm{H}, 1: 1$ ratio), 2.64 and 2.62 (two doublets , $J=15 \mathrm{~Hz}, J=15.6 \mathrm{~Hz}$, $1 \mathrm{H}, 1: 1$ ratio), $2.49(\mathrm{dd}, J=13.8,7.8 \mathrm{~Hz}, 1 \mathrm{H}), 2.21(\mathrm{dd}, J=13.8,7.8 \mathrm{~Hz}$, 1H), 1.29 and 1.13 (two singlets, $3 \mathrm{H}, 1: 1$ ratio); ${ }^{13} \mathrm{C} \mathrm{NMR}\left(150 \mathrm{MHz}, \mathrm{CDCl}_{3}\right.$, 
1:1 diastereomeric mixture) $\delta 142.9,141.8,135.5,132.1,131.9(2 \mathrm{C}), 131.7$, $128.2(2 \mathrm{C}), 127.8,127.4(2 \mathrm{C}), 126.9,126.5,126.1(2 \mathrm{C}), 124.7,124.5,123.3$, $117.4,92.9,92.7,88.4,83.9,49.4,48.2,45.0,42.7,24.9$.

Alkene 74. To a mixture of diacetylenic hydrocarbon 70 (500 mg, $1.3 \mathrm{mmol})$ in $50 \mathrm{~mL}$ of anhydrous toluene under a nitrogen atmosphere were added a solution of potassium tert-butoxide (180 $\mathrm{mg}, 1.56 \mathrm{mmol})$ in THF and $0.5 \mathrm{~mL}$ of 2-methyl-2-propanol. The reaction mixture was heated under reflux for 2 hr. After the reaction mixture was allowed to cool to room temperature, 20 $\mathrm{mL}$ of water and $50 \mathrm{~mL}$ of dichloromethane were added. The organic layer was separated, dried over $\mathrm{Na}_{2} \mathrm{SO}_{4}$, and concentrated. Flash column chromatography on silica gel $(5 \%$ EtOAc/hexanes) provided substituted alkene $74(370 \mathrm{mg}, 1.0 \mathrm{mmol})$ as a brown solid in $76 \%$ yield: $\mathrm{mp} 55-60{ }^{\circ} \mathrm{C}$; $\mathrm{R}_{f}(30 \%$ EtOAc/Hexanes $)=0.85$; IR (thin film, $\left.\mathrm{cm}^{-1}\right)$ 2955, 2908, 1736, 1604, 1441, 1376, 1238, 1028, 913, 773, 754, 727, 703; ${ }^{1} \mathrm{H}$ NMR (600 MHz, $\left.\mathrm{CDCl}_{3}\right) \delta$ 7.60-7.52 (m, 4H), 7.46-7.42 (m, 2H), 7.35-7.33 (m, 1H), 7.26$7.21(\mathrm{~m}, 3 \mathrm{H}), 7.02(\mathrm{dd}, J=7.8,7.2 \mathrm{~Hz}, 1 \mathrm{H}), 6.62(\mathrm{~d}, J=7.8 \mathrm{~Hz}, 1 \mathrm{H}), 5.66$ (m, 1H), $5.11(\mathrm{~m}, 1 \mathrm{H}), 4.98(\mathrm{~m}, 1 \mathrm{H}), 4.19(\mathrm{~d}, J=21.0,1 \mathrm{H}), 4.15(\mathrm{~d}, J=21.0$, $1 \mathrm{H}), 3.56(\mathrm{~d}, J=16.8 \mathrm{~Hz}, 1 \mathrm{H}), 3.16(\mathrm{~d}, J=16.8 \mathrm{~Hz}, 1 \mathrm{H}), 2.85-2.81(\mathrm{~m}, 1 \mathrm{H})$, 2.73-2.69 (m, 1H), $1.63(\mathrm{~s}, 3 \mathrm{H}) ;{ }^{13} \mathrm{C}$ NMR $\left(150 \mathrm{MHz}, \mathrm{CDCl}_{3}\right) \delta 145.7,144.2$, $142.9,141.6,138.8,137.0,135.2,133.2,131.0130 .7,130.2,130.1,128.9$ 
(2C), 127.5 (2C), 127.3, 126.8, 126.4, 124.8, 123.7, 121.4, 119.0, 117.5, 47.7, $44.6,44.5,34.0,26.6$.

11H-benzo[b]fluorene iodide 75 . A solution of alkene $74(100 \mathrm{mg}, 0.26$ mmol) in THF $(10 \mathrm{~mL})$ was added over $5 \mathrm{~min}$ to a solution of disiamylborane ( 1 equiv, $0.26 \mathrm{mmol}$,) at $0{ }^{\circ} \mathrm{C}$. After the reaction mixture was stirred at $\mathrm{rt}$ for $2 \mathrm{hr}$ iodine $(151 \mathrm{mg}, 1.2 \mathrm{mmol})$ was added all at once followed by a solution of $\mathrm{NaOH}(50 \mathrm{mg}, 1.2 \mathrm{mmol})$ in $2 \mathrm{~mL}$ of methanol. The reaction mixture was stirred for another $30 \mathrm{~min}$, and then quenced with aq. satd. $\mathrm{NH}_{4} \mathrm{Cl}$. Diethyl ether was added and the organic phase was separated, dried over $\mathrm{Na}_{2} \mathrm{SO}_{4}$, and concentrated. Silica gel column chromatography $(2 \% \quad$ EtOAc/hexanes $)$ provided $11 H$-benzo $[b]$ fluorene iodide 75 (87 g, $0.17 \mathrm{mmol})$ as a yellow liquid in 65\% yield: $\mathrm{R}_{f}(30 \%$ EtOAc/Hexanes) = 0.69; IR (thin film, $\mathrm{cm}^{-1}$ ) 2827, 1698, 1601, 1263, 1027, 908, 725; ${ }^{1} \mathrm{H}$ NMR (600 MHz, $\left.\mathrm{CDCl}_{3}\right) \delta$ 7.60-7.54 (m, 4H), 7.53-7.42 (m, 2H), $7.35(\mathrm{dd}, J=8.4,6.6,1 \mathrm{H}), 7.26-7.21(\mathrm{~m}, 3 \mathrm{H}), 7.02(\mathrm{dd}, J=7.8,7.2 \mathrm{~Hz}$, $1 \mathrm{H}), 6.62(\mathrm{~d}, J=7.8 \mathrm{~Hz}, 1 \mathrm{H}), 4.19(\mathrm{~d}, J=21.0,1 \mathrm{H}), 4.15(\mathrm{~d}, J=21.0,1 \mathrm{H})$, $3.48(\mathrm{~d}, J=16.8 \mathrm{~Hz}, 1 \mathrm{H}), 3.26(\mathrm{~d}, J=16.8 \mathrm{~Hz}, 1 \mathrm{H}), 3.15(\mathrm{t}, J=6.6 \mathrm{~Hz}, 2 \mathrm{H})$, 2.26-2.21 (m, 1H), 2.07-2.02 (m, 1H), 1.81-1.69 (m, 2H), $1.64(\mathrm{~s}, 3 \mathrm{H}) ;{ }^{13} \mathrm{C}$ NMR $\left(150 \mathrm{MHz}, \mathrm{CDCl}_{3}\right) \delta 145.1,144.1,141.5,142.6,139.7,138.2,138.7$, 133.3, 131.0, 130.8, 130.1 (2C), 129.0 (2C), 127.6, 127.3, 126.9, 126.4, 
$124.9,123.7,121.5,119.0,47.5,45.3,41.1,33.9,29.3,27.3,7.7$.

Polycyclic Aromatic Hydrocarbon 76. To a solution of alkyl iodide 75 (90 $\mathrm{mg}, 0.18 \mathrm{mmol})$ in THF $(50 \mathrm{~mL})$ was added a solution of $t$-BuOK $(30 \mathrm{mg}$, $0.27 \mathrm{mmol}$ ) in THF. The reaction mixture was heated to $40{ }^{\circ} \mathrm{C}$ for $2 \mathrm{hr}$ and quenced with aq satd. $\mathrm{NH}_{4} \mathrm{Cl}$. The reaction mixture was extracted with $\mathrm{Et}_{2} \mathrm{O}$, and the organic phase was dried over $\mathrm{Na}_{2} \mathrm{SO}_{4}$ and concentrated. Silica gel column chromatography (2\% EtOAc/hexanes) provided the polycyclic aromatic hydrocarbon 76 (40 $\mathrm{mg}, 0.10 \mathrm{mmol})$ as a yellow liquid in $60 \%$ yield: $\mathrm{R}_{f}(30 \%$ EtOAc/Hexanes $)=0.71$; IR (thin film, $\left.\mathrm{cm}^{-1}\right) 2924,2852$, $1698,1602,1442,1377,1265,1158,1070,1027,914,774,751,731,706$;

${ }^{1} \mathrm{H}$ NMR $\left(600 \mathrm{MHz}, \mathrm{CDCl}_{3}\right) \delta$ 7.60-7.40 (m, 6H), $7.35(\mathrm{dd}, J=8.4,6.6,1 \mathrm{H})$, 7.28-7.21 (m, 3H), $7.02(\mathrm{dd}, J=7.8,7.2 \mathrm{~Hz}, 1 \mathrm{H}), 6.64$ (d, $J=7.8 \mathrm{~Hz}, 1 \mathrm{H})$, $4.20(\mathrm{dd}, J=12.0,3.6 \mathrm{~Hz}, 1 \mathrm{H}), 3.35(\mathrm{~d}, J=16.8 \mathrm{~Hz}, 1 \mathrm{H}), 3.29(\mathrm{~d}, J=16.8$ Hz, 1H), $2.58(\mathrm{~m}, 1 \mathrm{H}), 2.42(\mathrm{~m}, 1 \mathrm{H}), 2.25(\mathrm{~m}, 1 \mathrm{H}), 2.17(\mathrm{~m}, 1 \mathrm{H}), 1.89(\mathrm{~m}$, 1H), $1.60(\mathrm{~s}, 3 \mathrm{H}), 1.33(\mathrm{~m}, 1 \mathrm{H}) ;{ }^{13} \mathrm{C} \mathrm{NMR}\left(150 \mathrm{MHz}, \mathrm{CDCl}_{3}\right) \delta$ 148.6, 147.1, $143.3,141.4,139.5,138.7,137.8,136.2,130.8,130.4,130.1,129.9,128.9$, $128.8,127.5,127.3,126.9,126.6,124.0,123.5,121.4,119.2,48.9,47.3$, 47.1, 40.3, 33.4, 26.6, 25.1; CIHRMS: Calculated for $\left[\mathrm{C}_{29} \mathrm{H}_{24}+\mathrm{H}\right]^{+}$: 373.1956, Found: 373.1951. 


\section{References:}

1 Kroto, H. W.; Heath, J. R.; O’Brien, S. C.; Curl, R. F.; Smalley, R. E. Nature. 1985, 318, 162.

2 Culotta, E.; Koshland, D. E. Science. 1991, 254, 1706.

3 Rabideau, P. W.; Sygula, A. Acc. Chem. Res. 1996, 29, 235 and references therein.

4 (a) Vikki, M. T.; Lawerence; T. S. Chem. Rev. 2006, 106, 4868. (b) Scott,

L. T. Pure and Appl. Chem. 1996, 68, 291 and refrences therein. (c) McComas, C. C.; B.S. Thesis, Boston College, Chestnut Hill, MA, 1997. (d) Mehta, G.; Rao, H. S. P. Tetrahedron. 1998, 54, 13325. (e) Scott, L. T.; Hashemi, M. M.; Meyer, D. T.; Warren, H. B. J. Am. Chem. Soc. 1991, 113, 7082.

5 Barth, W. E.; Lowton, R. G.; J. Am. Chem. Soc. 1966, 88, 380.

6 (a) Sygula, A.; Abdourazak, A. H.; Rabideau, P. W. J. Am. Chem. Soc. 1996, 118, 339. (b) Sygula, A.; Rabideau, P. W. J. Am. Chem. Soc. 1999, 121, 7800. (c) Seiders, T. J.; Elliott, E. L.; Grube, G. H. J. Am. Chem. Soc. 1999, $121,7804$.

7 (a) Meyer, D. T. M.S. Thesis, University of Neveda, Reno, 1991. (b) Bratcher, M.S. Ph. D. Dissertation, Boston College, Chestnut Hill, MA, 1996. (c) McMahan, B.J. B. S. Thesis, Boston College, Chestnut Hill, MA, 
1997. (d) Mehta, G.; Srirama Sarma, P. V. V. Chem.Commun. 2000, 19

8 (a) Sygula, A.; Abdourazak, A. H.; Rabideau, P. W. J. Am. Chem. Soc.

1994, 116, 7891. (b) Clayton, M. D.; Marcinow, Z. Rabideau, P. W. J. Org.

Chem. Soc. 1996, 61, 6052. (c) Mehta, G. Chem.Commun.. 1997, 2081. (d)

Sygula, A.; Rabideau, P. W. J. Am. Chem. Soc. 1998, 120, 12666.

9 (a) Cohen, Y.; Klein, J.; Rabinovitz, M. J. Chem. Soc., Chem.Commun.

1986, 1071. (b) Harvey, R. G.; Abu- Shaqara, E.; Yang, C. J. Org. Chem.

1993, 58, 5866. (c) Barth, W. E.; Lawton, R. G. J. Am. Chem. Soc. 1971, 93, 1730.

10 (a) Zhang, H. R.; Wang, K. K. J. Org. Chem. 1999, 64, 7996. (b) Zhang, H. R.; Ph. D. Dissertation, West Virginia University, 2000, (c) Seiders, T. J.; Baldrige, K. K.; Siegel, J. S. J. Am. Chem. Soc. 1996, 118, 2754. (d) Hongbin, Li.; Wang, K. K. J. Org. Chem. 2001, 66, 6662-6668. (e) Wang, K. K. Chem. Rev. 1996, 96, 207-222. (f) Wang, K. K.; Zhang, H.-R.; Petersen, J. L. J. Org. Chem. 1999, 64, 1650-1656.

11 (a) Myers, A. G.; Kuo, E. Y.; Finney, N. S. J. Am. Chem. Soc. 1989, 111, 8057-8059. (b) Myers, A. G.; Dragovich, P. S. J. Am. Chem. Soc. 1989, 111, 9130-9132. (c) Nagata, R.; Yamanaka, H.; Okazaki, E.; Saito, I. Tetrahedron Lett. 1989, 30, 4995-4998. (d) Nagata, R.; Yamanaka, H.; Murahashi, E.; Saito, I. Tetrahedron Lett. 1990, 31, 2907-2910. 
12 (a) Schmittel, M.; Strittmatter, M.; Kiau, S. Tetrahedron Lett. 1995, 36, 4975-4978. (b) Schmittel, M.; Strittmatter, M.; Vollmann, K.; Kiau, S. Tetrahedron Lett. 1996, 37, 999-1002. (c) Schmittel, M.; Strittmatter, M.; Kiau, S. Angew. Chem., Int. Ed. Engl. 1996, 35, 1843-1845. (d) Schmittel, M.; Kiau, S.; Siebert, T.; Strittmatter, M. Tetrahedron Lett. 1996, 37, 76917694. (e) Schmittel, M.; Keller, M.; Kiau, S.; Strittmatter, M. Chem.-Eur. J. 1997, 3, 807-816. (f) Schmittel, M.; Steffen, J.-P.; Maywald, M.; Engels, B.; Helten, H.; Musch, P. J. Chem. Soc., Perkin Trans. 2 2001, 1331-1339.

13 Wang, K. K.; Wang, Z.; Sattsangi, P. D. J. Org. Chem. 1996, 61, 15161518.

14 Jacobs, T. L.; Fenton, D. M. J. Org. Chem. 1965, 30, 1808-1812.

15 Carey, F. A.; Hsu, C. L. W. J. Organomet. Chem. 1969, 19, 29-41.

16 (a) Landor, P. D. in The Chemistry of the Allenes; Landor, S. R. Ed.; Acadamic Press: London 1982, Vol. 1, pp 44-47. (b) Kuhn, R.; Rewicki, D. Chem. Ber. 1965, 98, 2611-2618.

17 Yonghong, Y.; Wang, K. K.; Petersen, J. L. J. Org. Chem. 2003, 68, $5832-5837$.

18 Kim, D.; Petersen, J. L.; Wang, K. K. Org. Lett. 2006, 8, 2313-2316.

19 Bradshaw, J. D.; Guo, L.; Tessier, C. A.; Youngs, W. J. Organomettalics. 1996, $15,2582-2584$. 
20 Reisch, H. A.; Bratcher, M. S.; Scott, L. T. Org. Lett. 2000, 2, 1427-1430.

21 Seidel, G.; Laurich, D.; Furstner, A. J. Org. Chem. 2004, 69, 3950-3952.

22 Maciej, A.; Watt, D. S. J. Org. Chem. 1984, 49, 4226-4227.

23 Hongbin, Li.; Wang, K. K. J. Org. Chem. 2001, 66, 7804-7810.

24 (a) Brown, H. C.; Moerikofer, A. W. Organic and Biological Chemistry. 1961, 83, 3417-3422. (b) Brown, H. C.; Rathke, M. W.; Rogic, M. M. J. Am. Chem. Soc. 1968, 90, 5038-5040. 


\section{Appendix}

\section{( ${ }^{1} \mathrm{H}$ NMR, ${ }^{13} \mathrm{C}$ NMR and IR Spectra)}




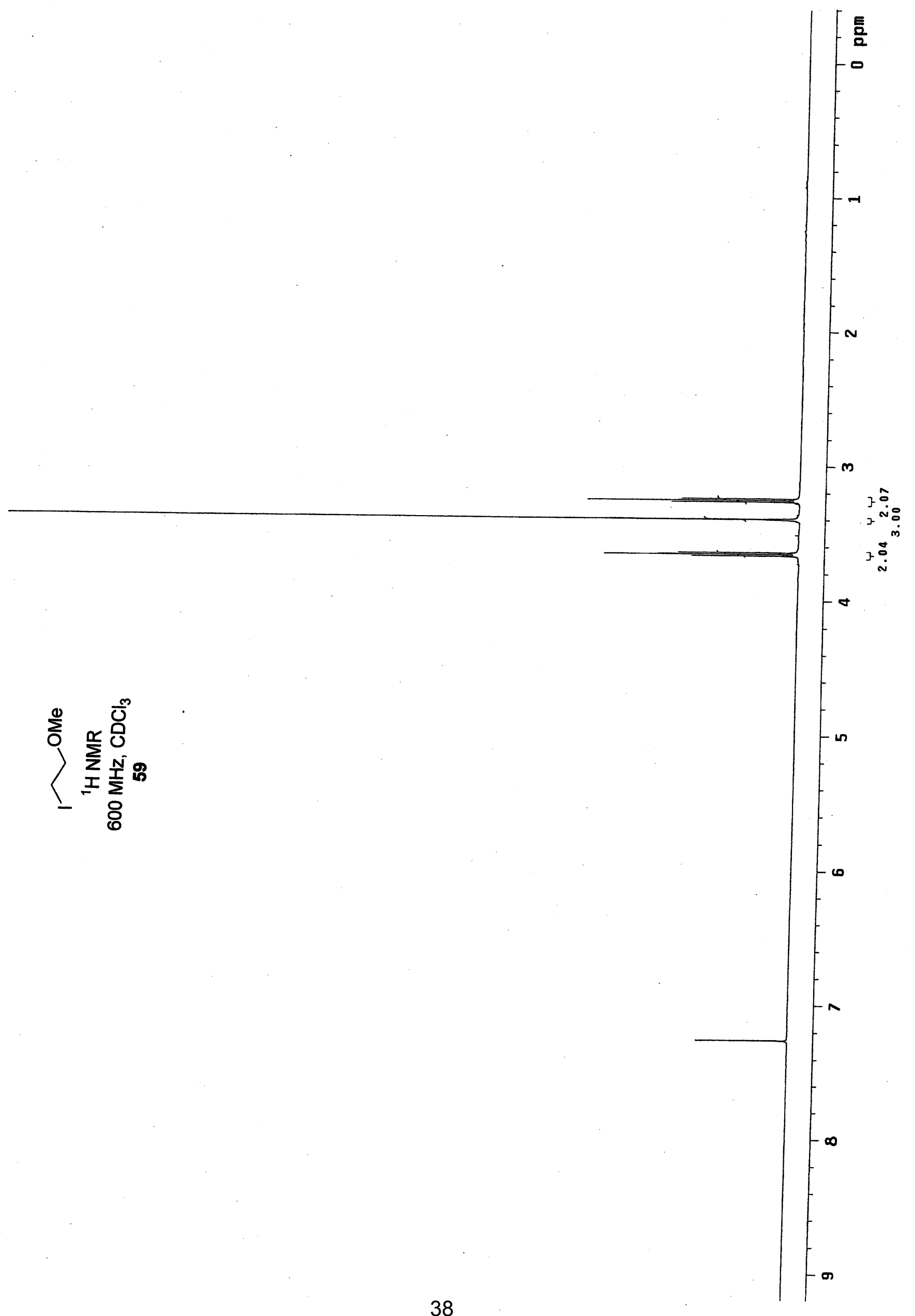




$$
\Rightarrow
$$




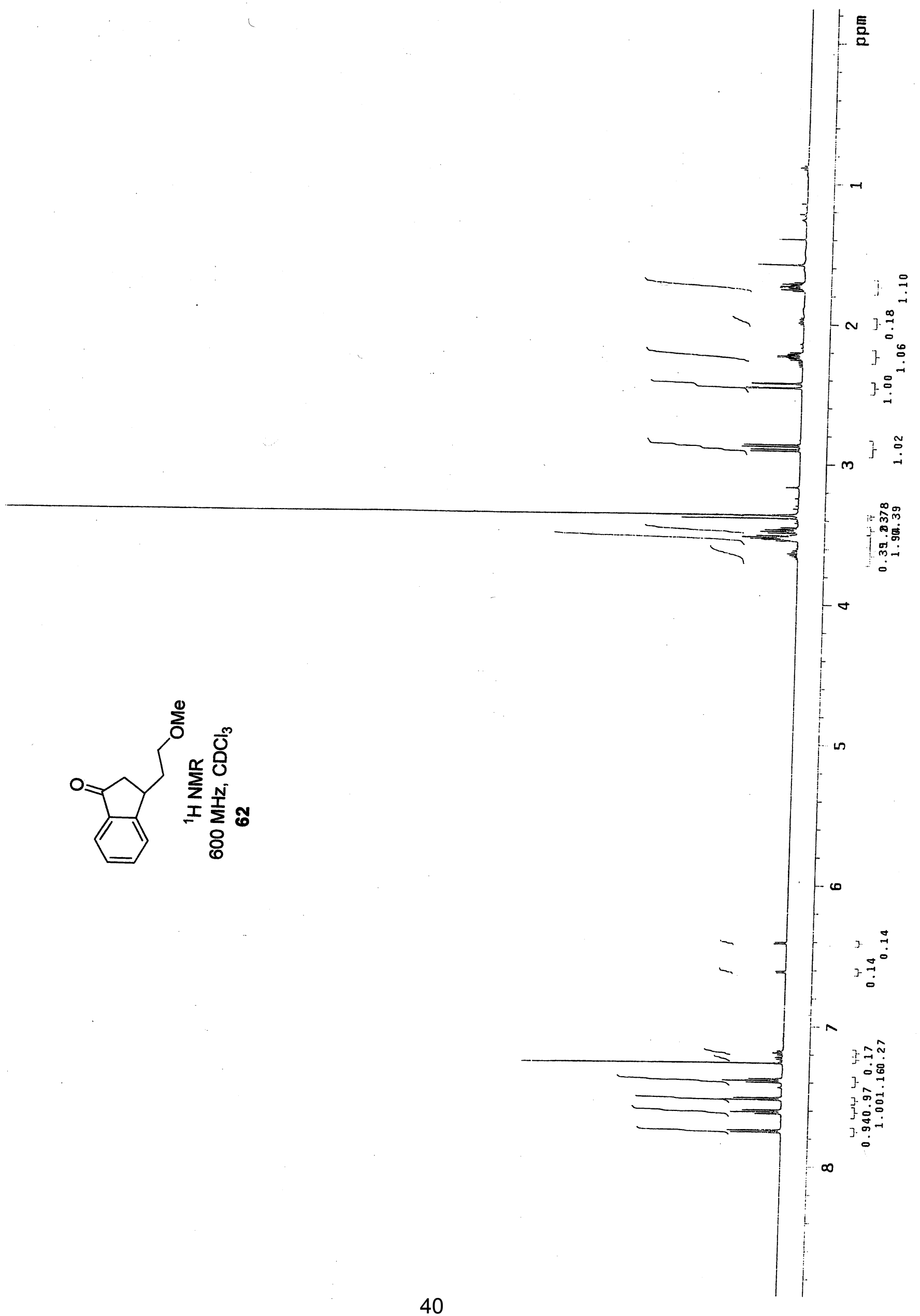




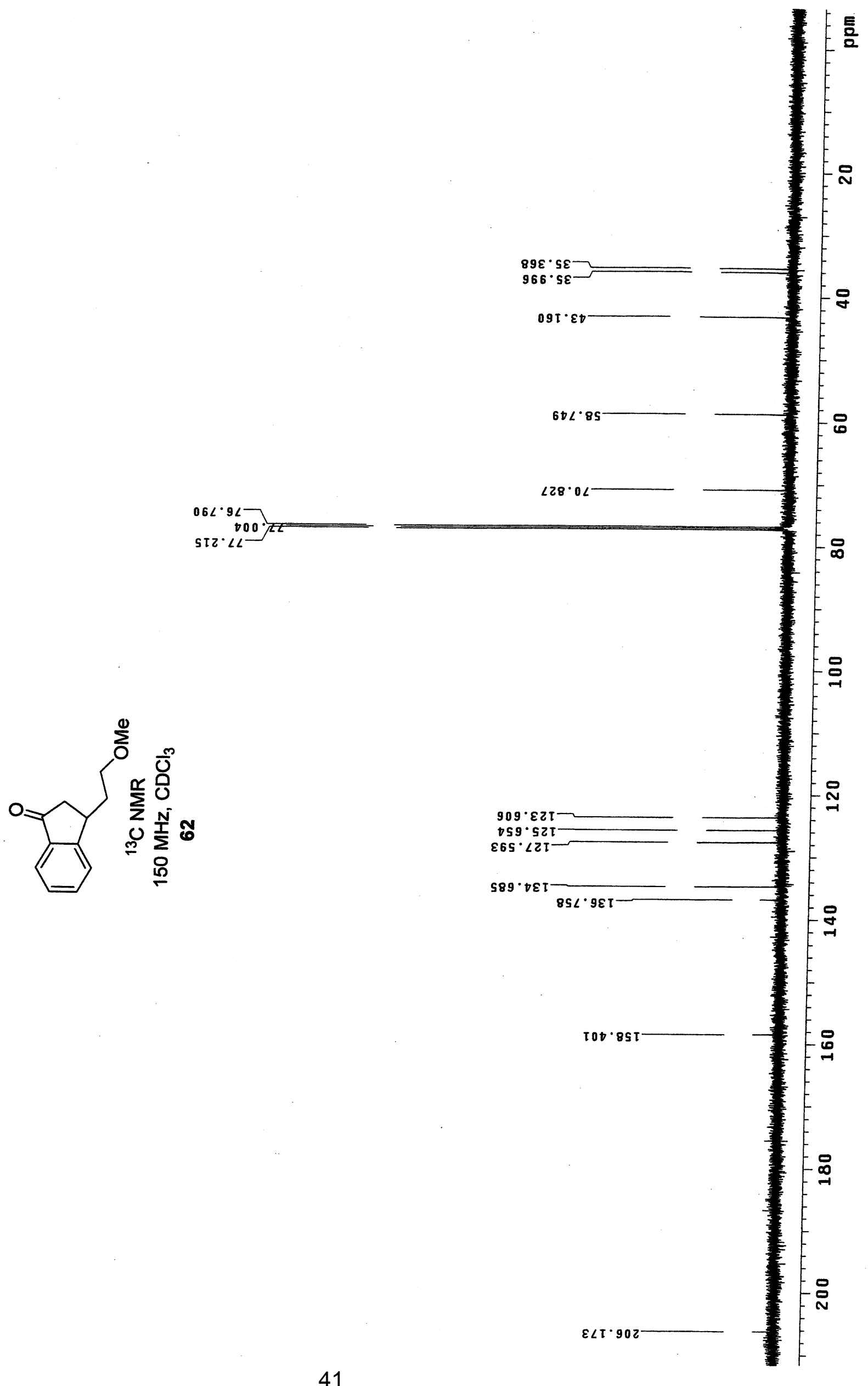




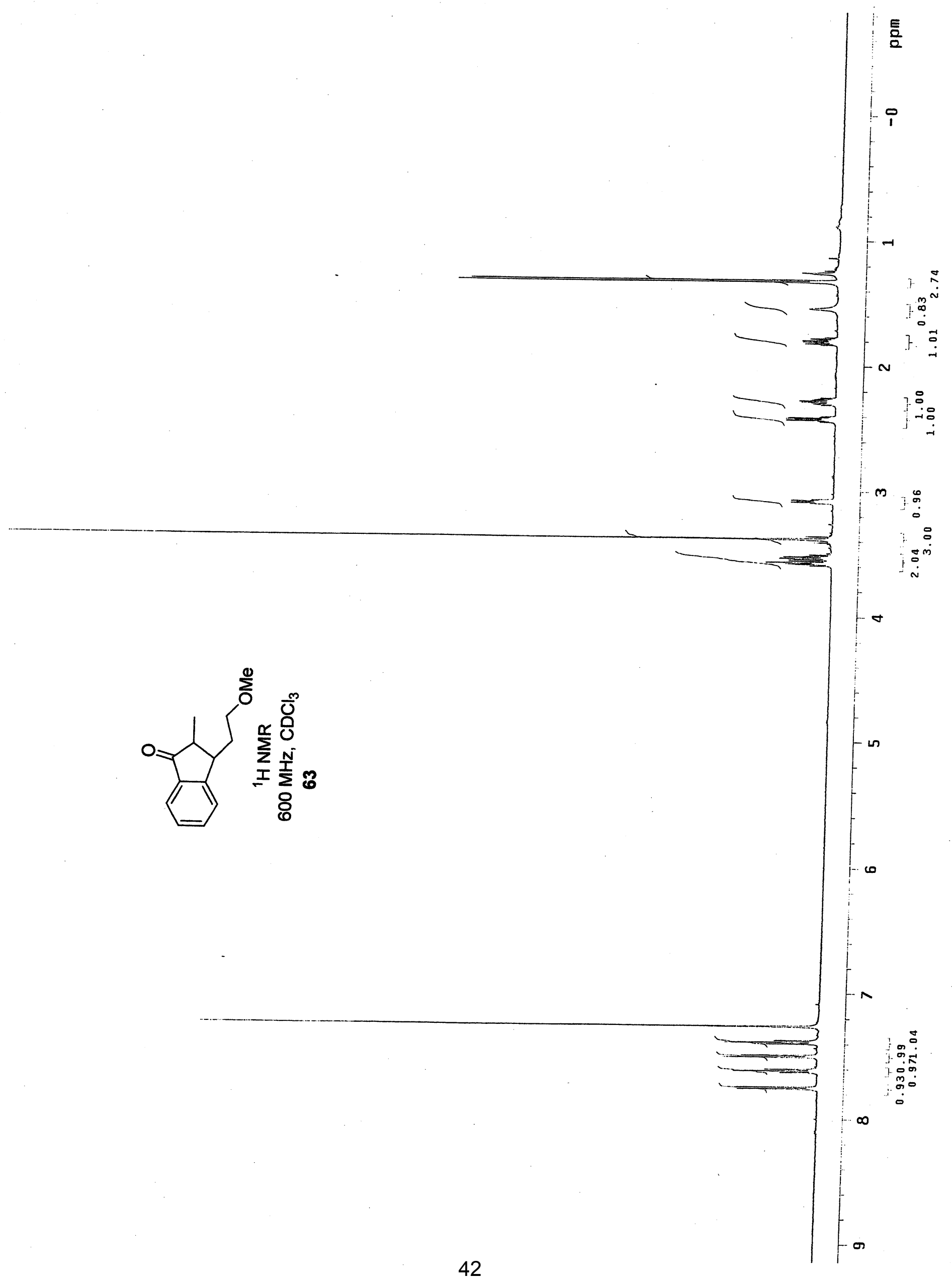




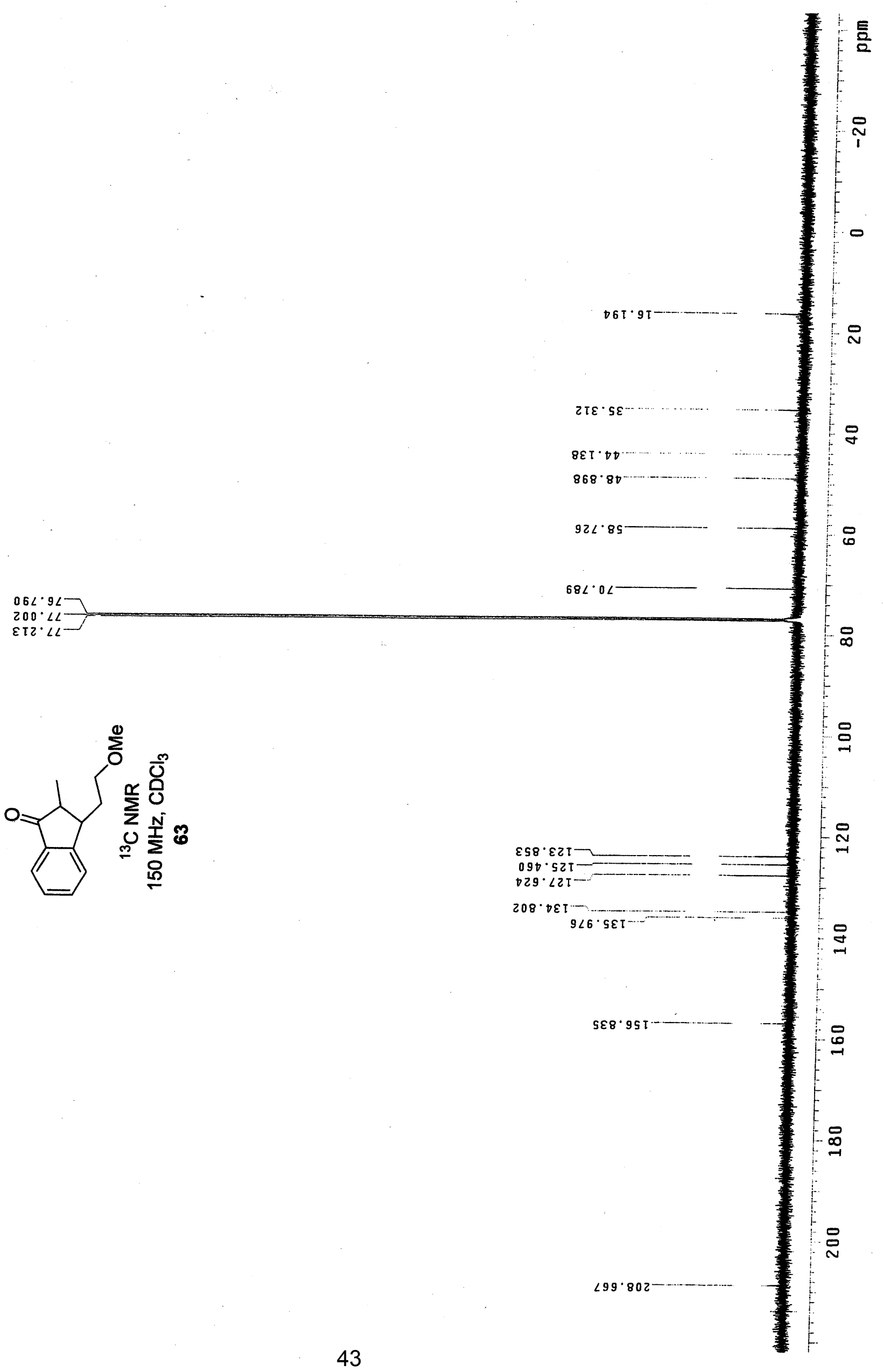




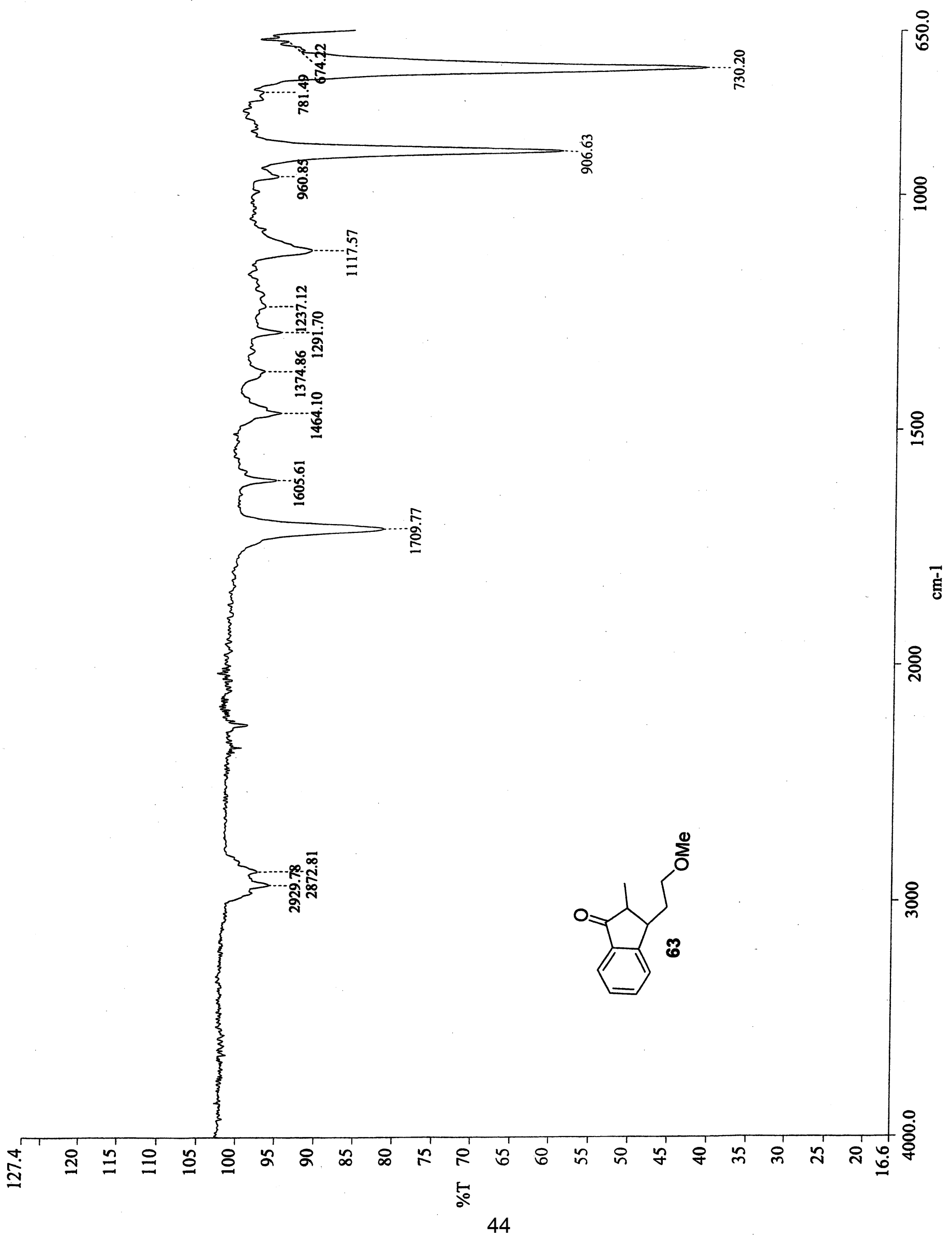




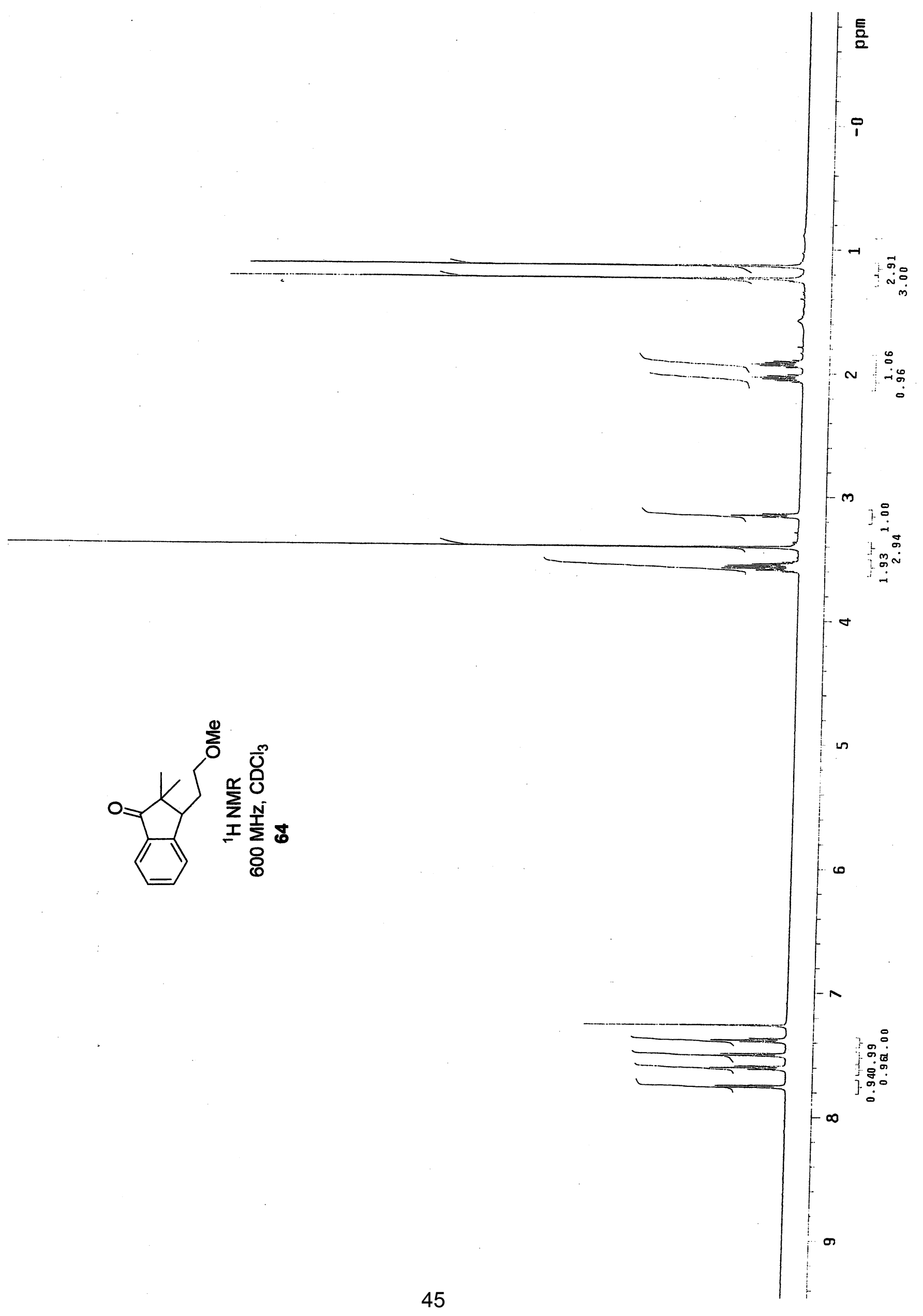




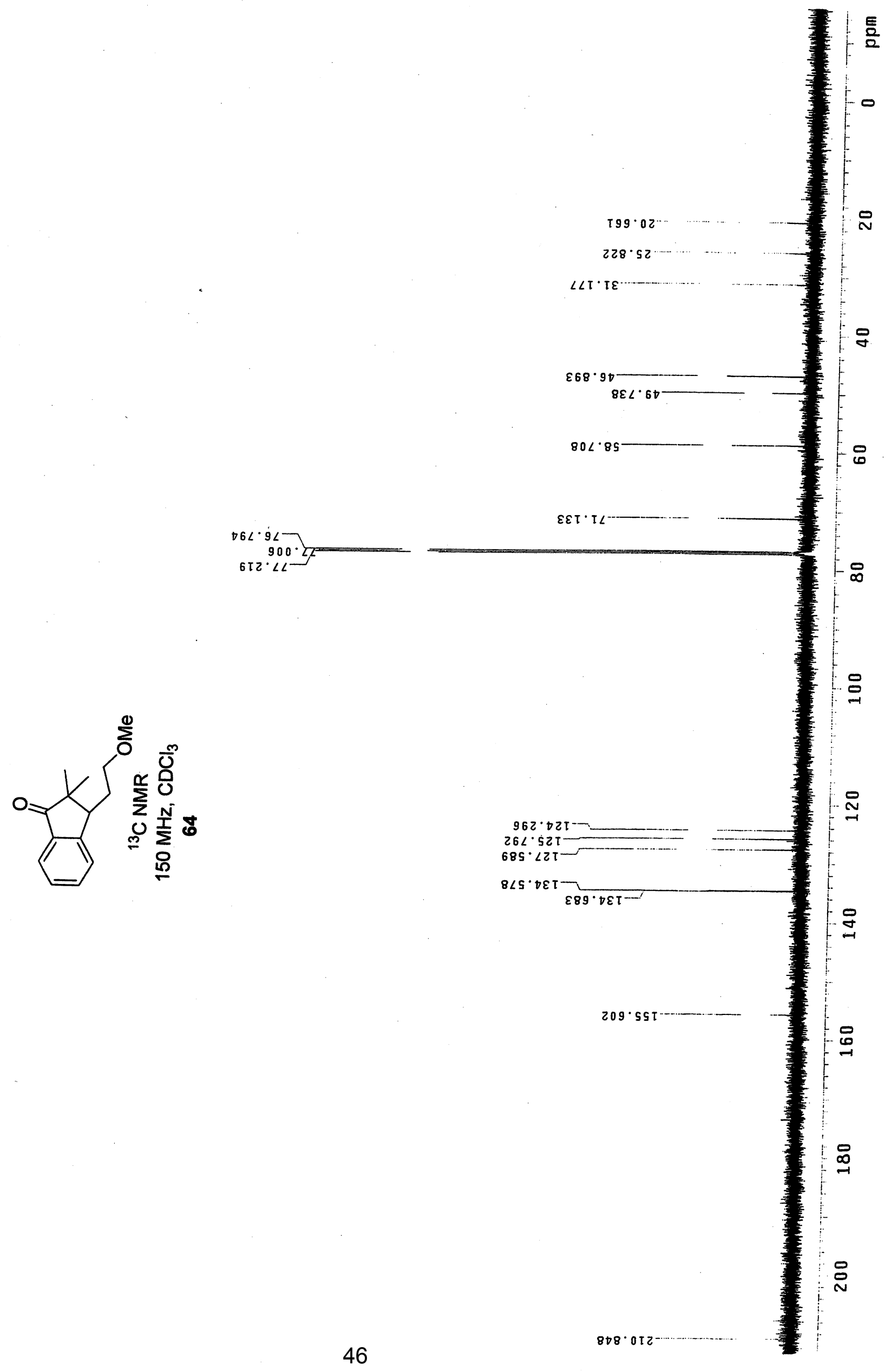




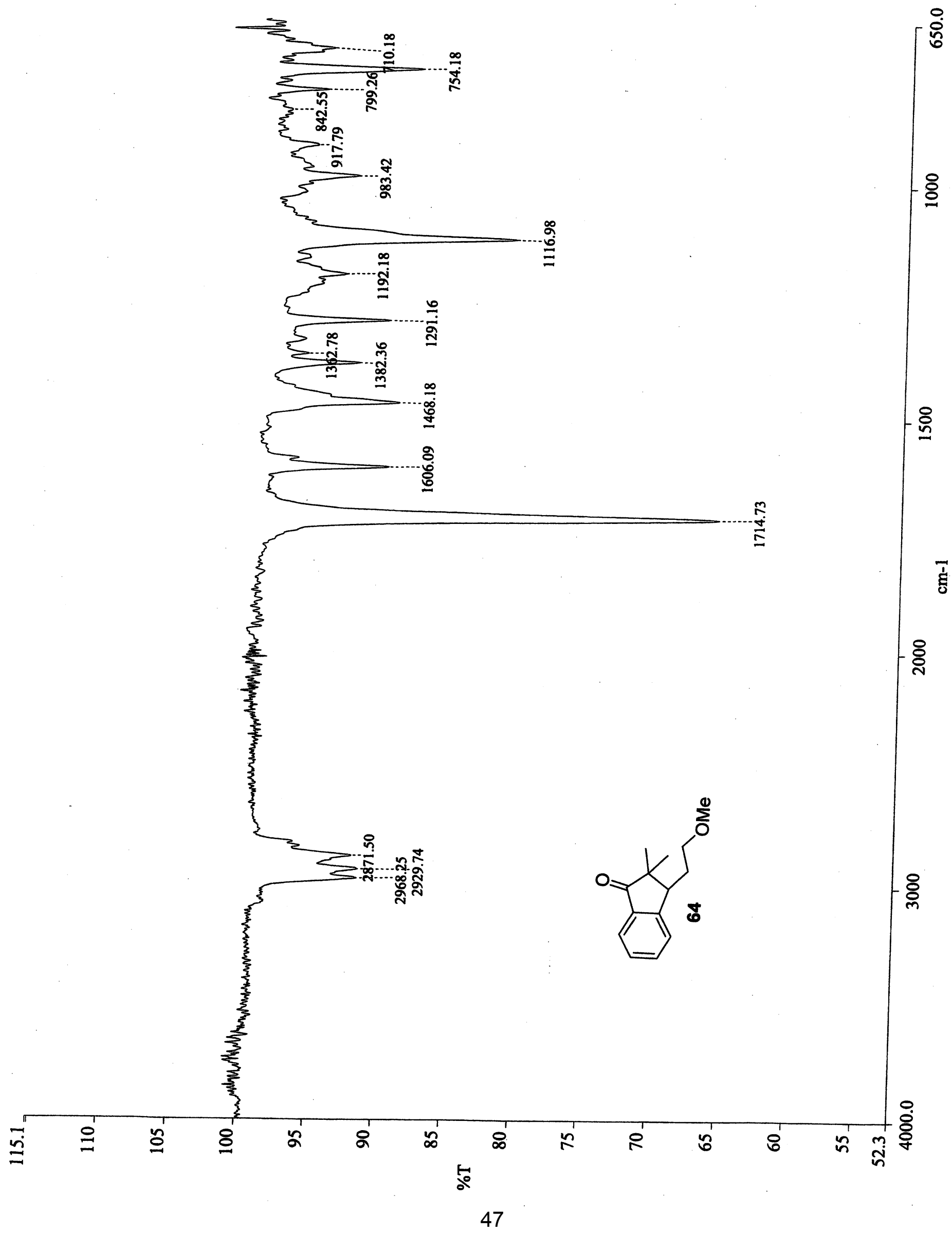




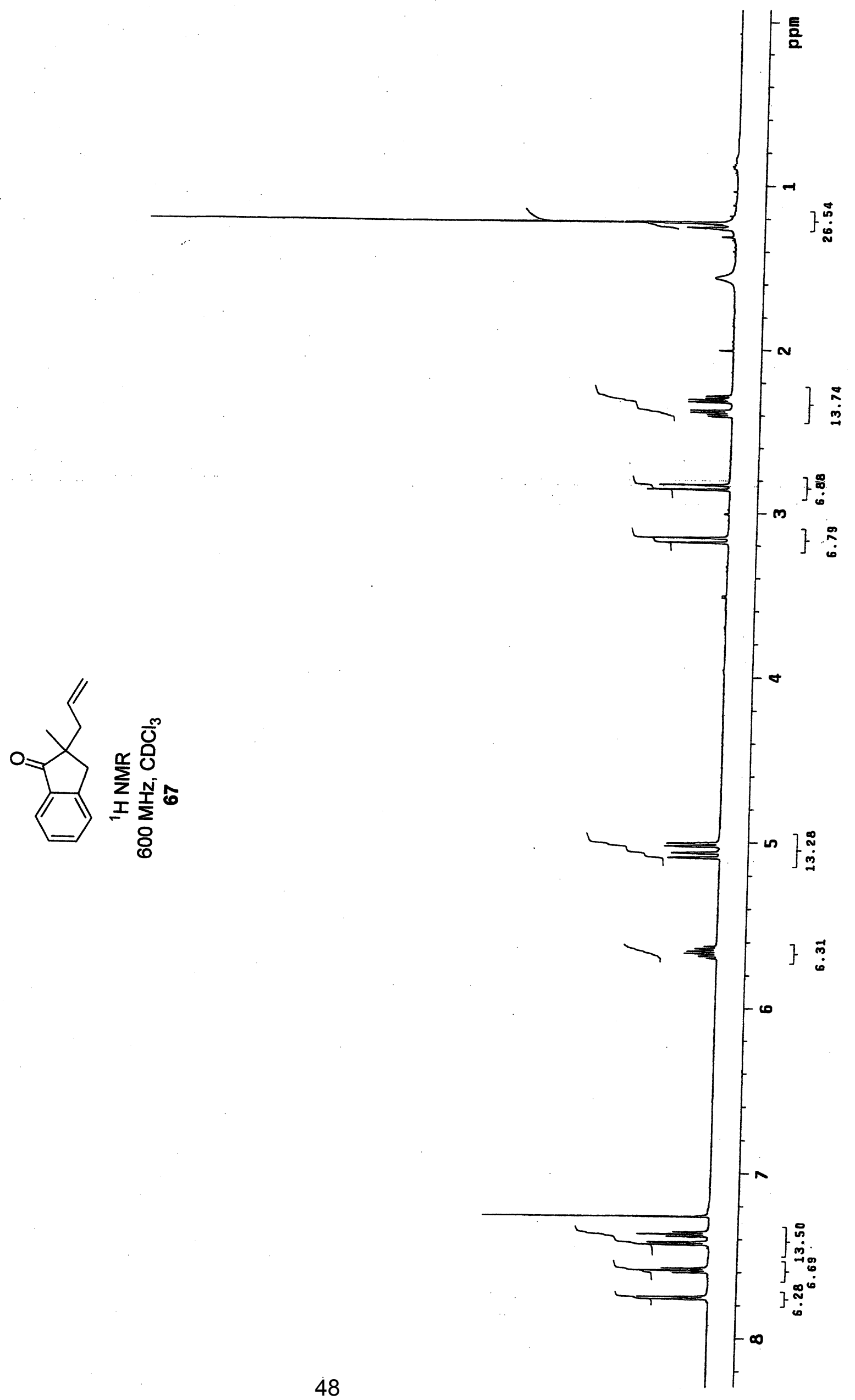




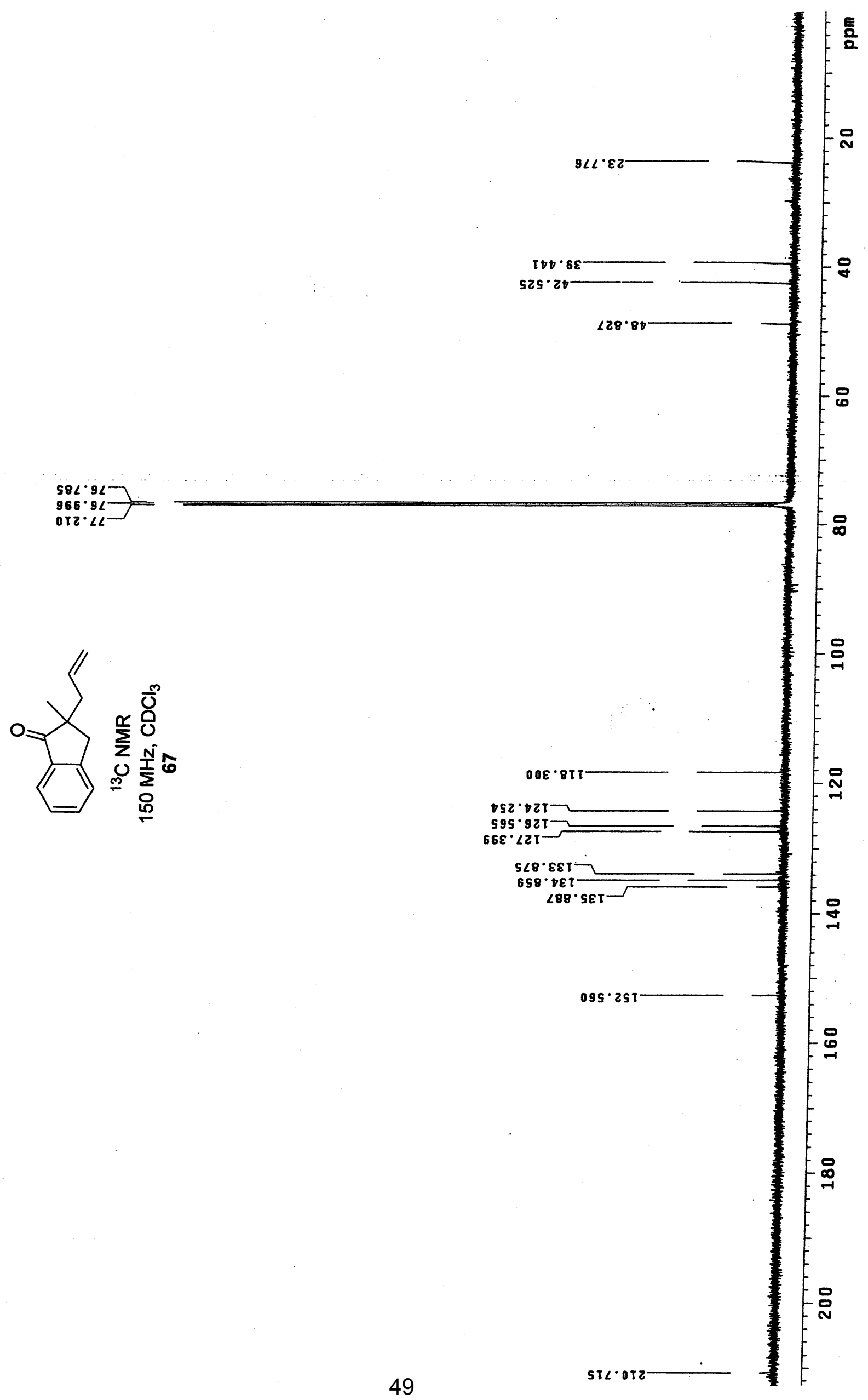




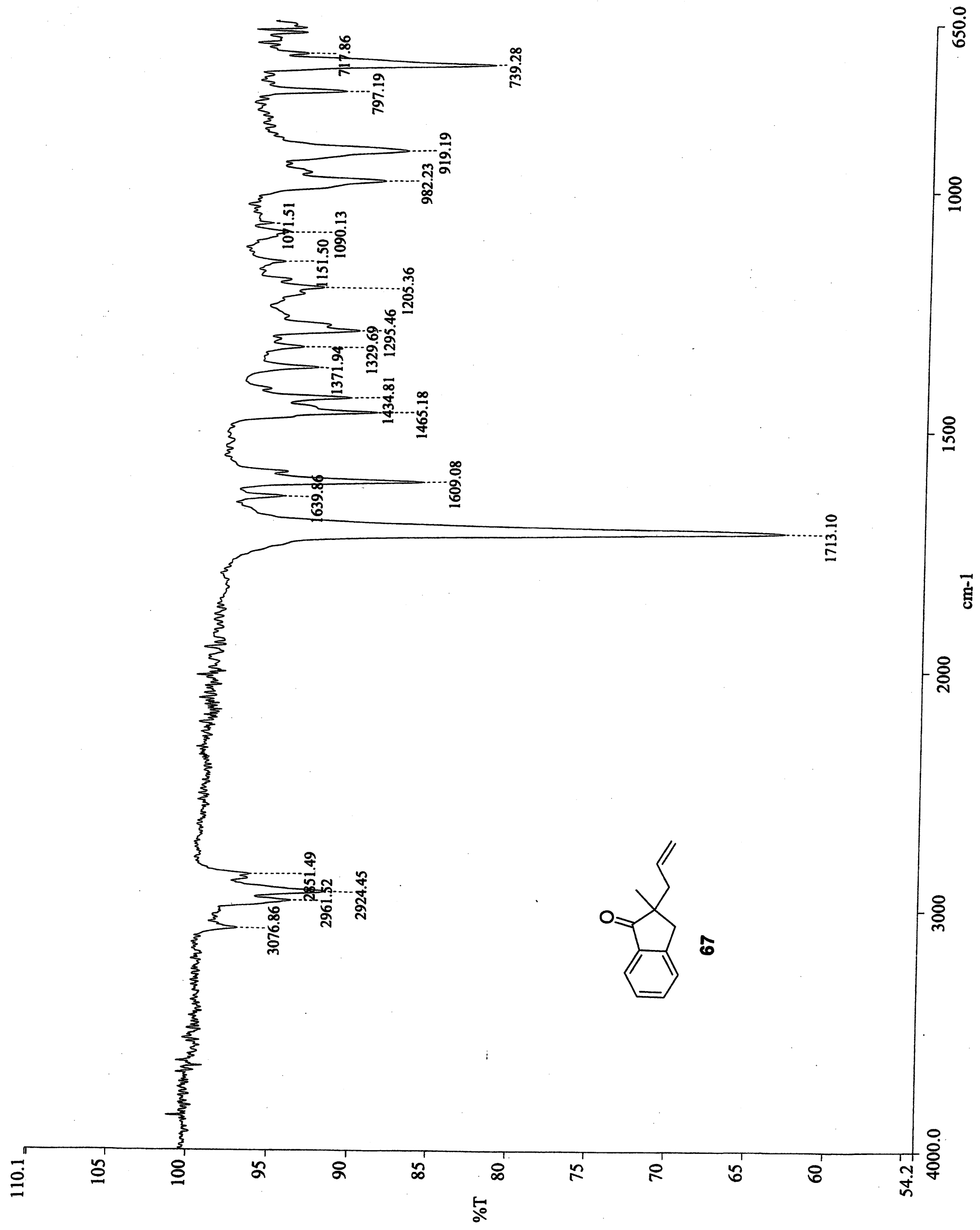




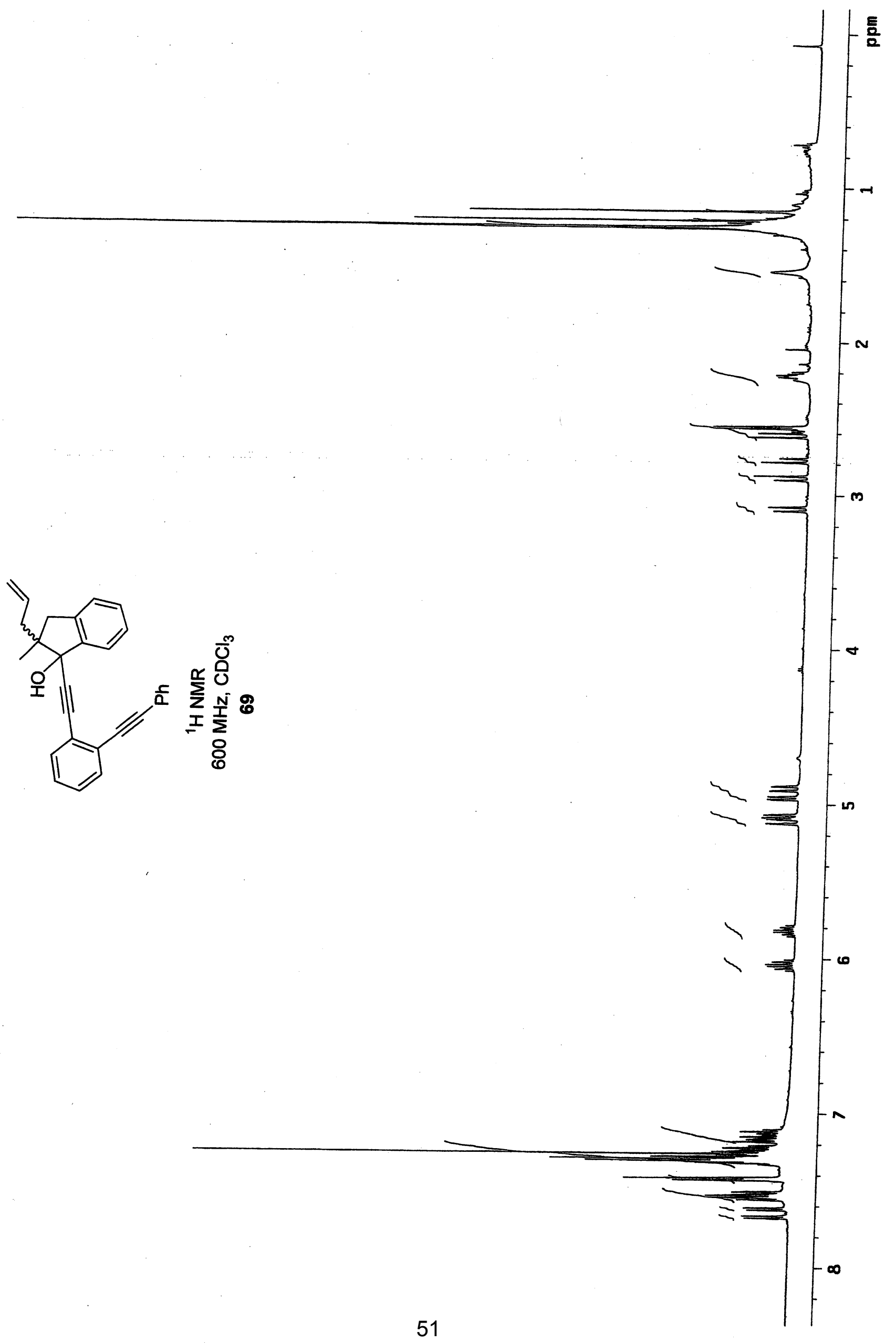



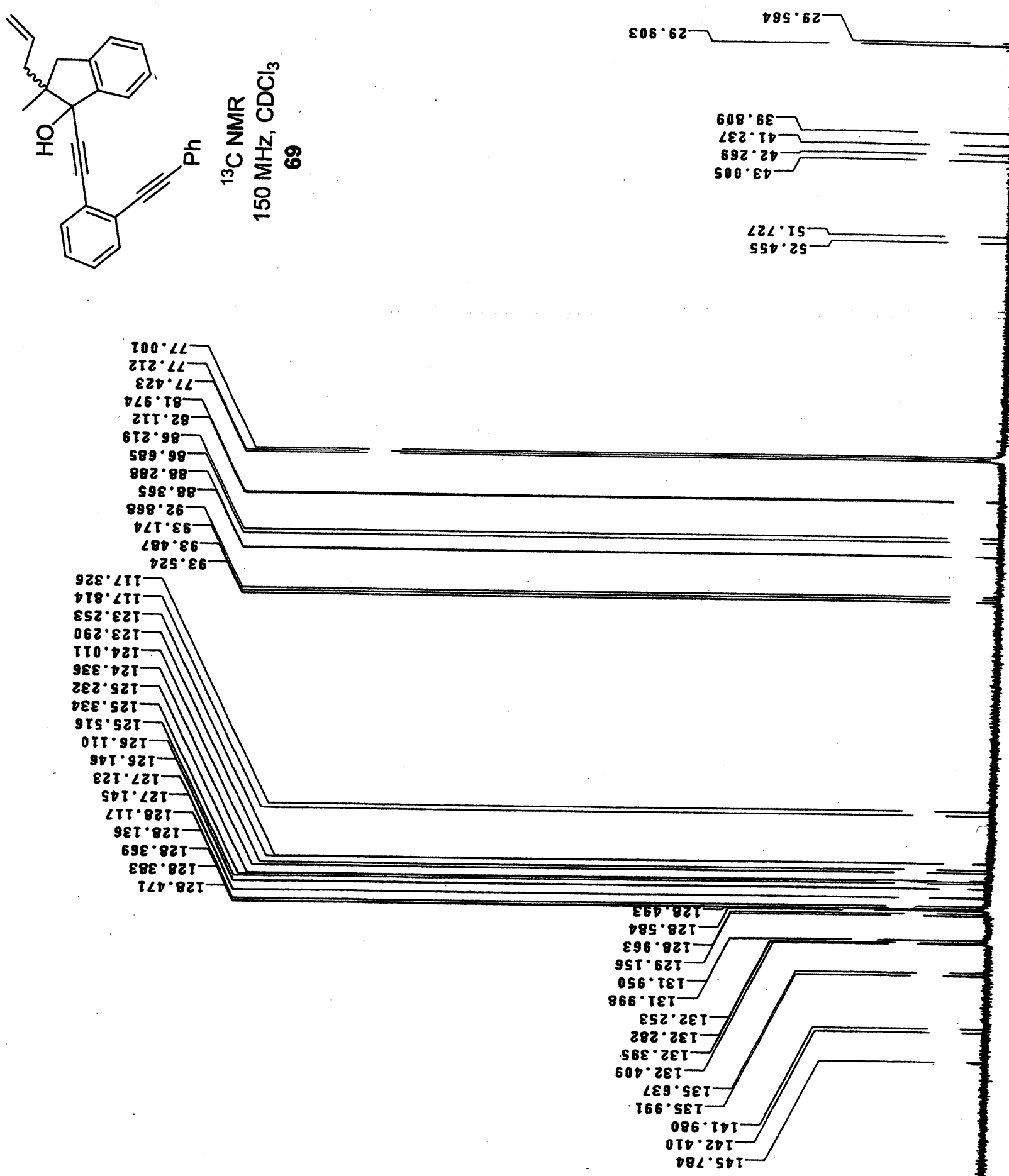

SSt.25 


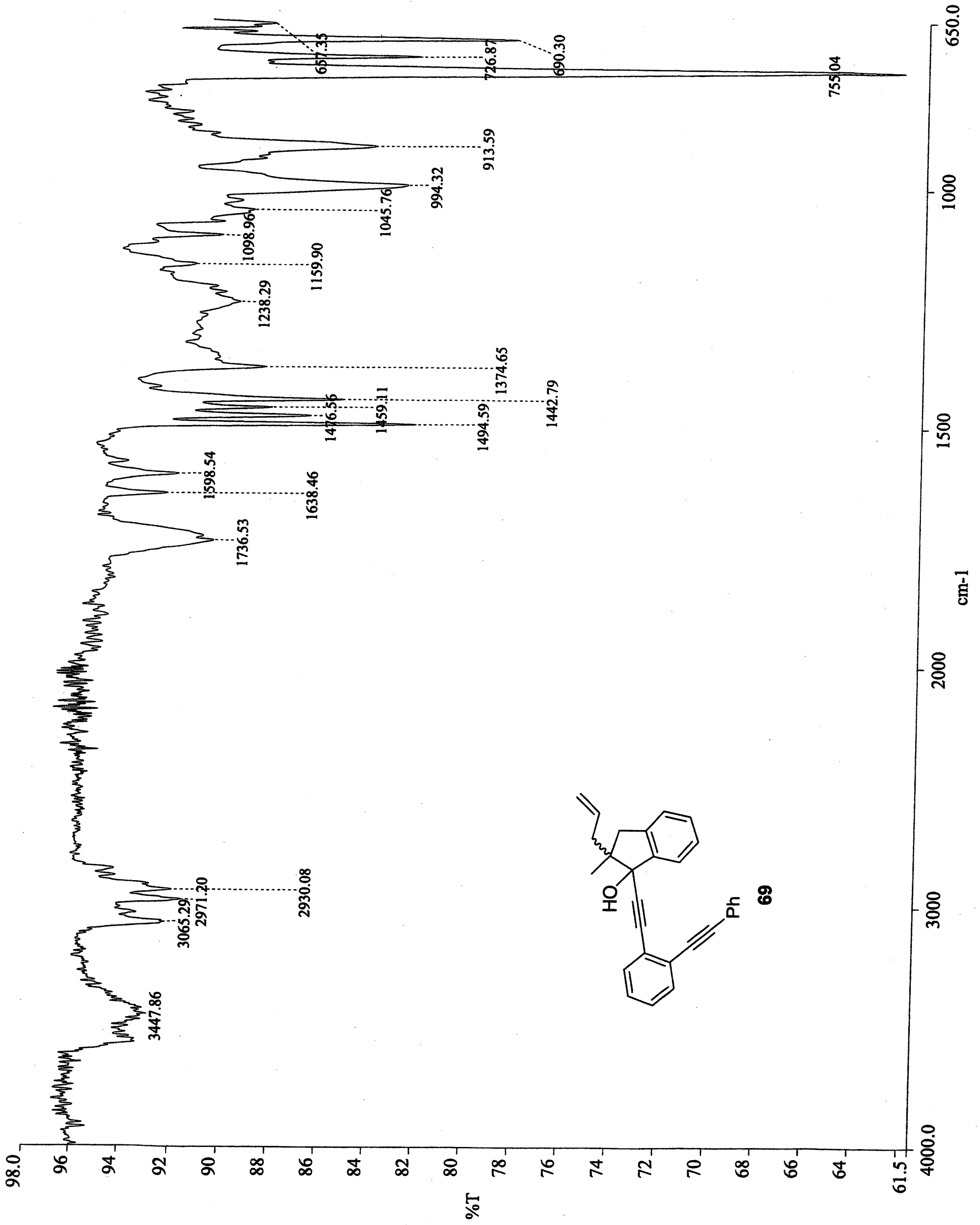




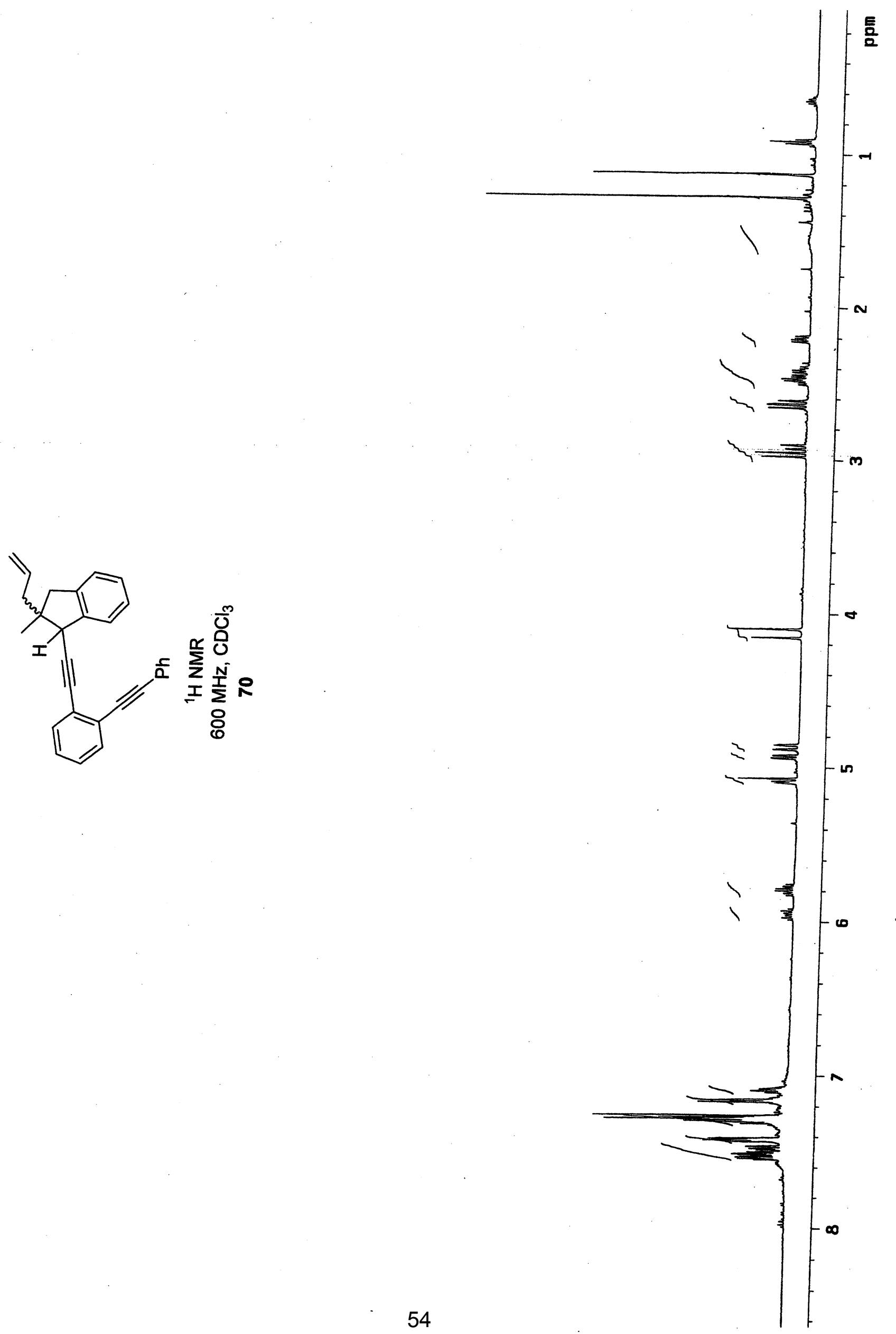


$58<\cdot 9 L$

$966^{\circ} 92$

$802^{\circ} \angle L$
$962 \cdot 88^{\circ}$

$962 \cdot 88$
$\tau 86.88$

$810 \cdot 88$

780.88

$6 \angle E^{\circ} 26$

DSL 26
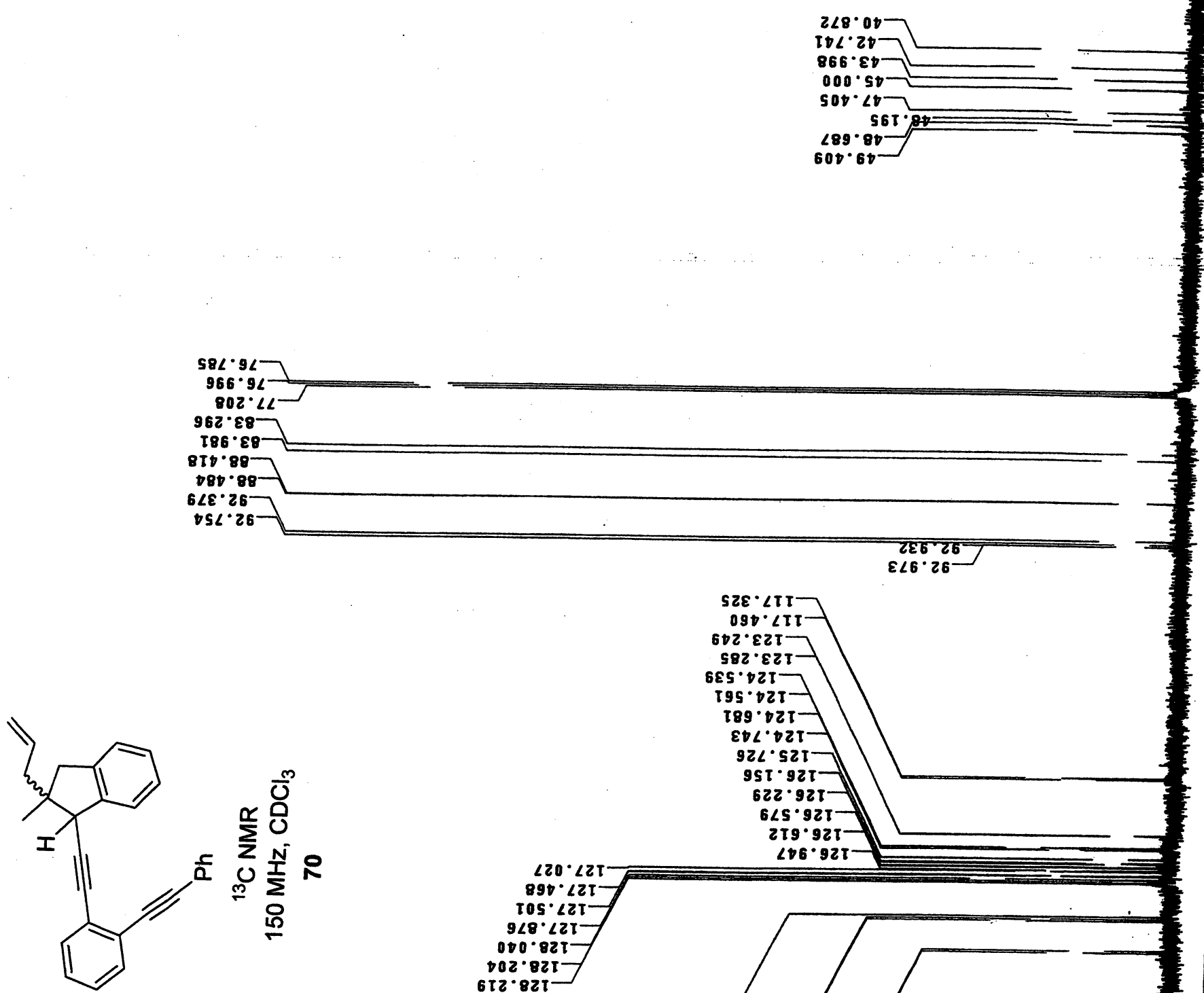

$600^{\circ} 60$

ยTย・て

$\varepsilon \varepsilon 6^{\circ} \nabla z$

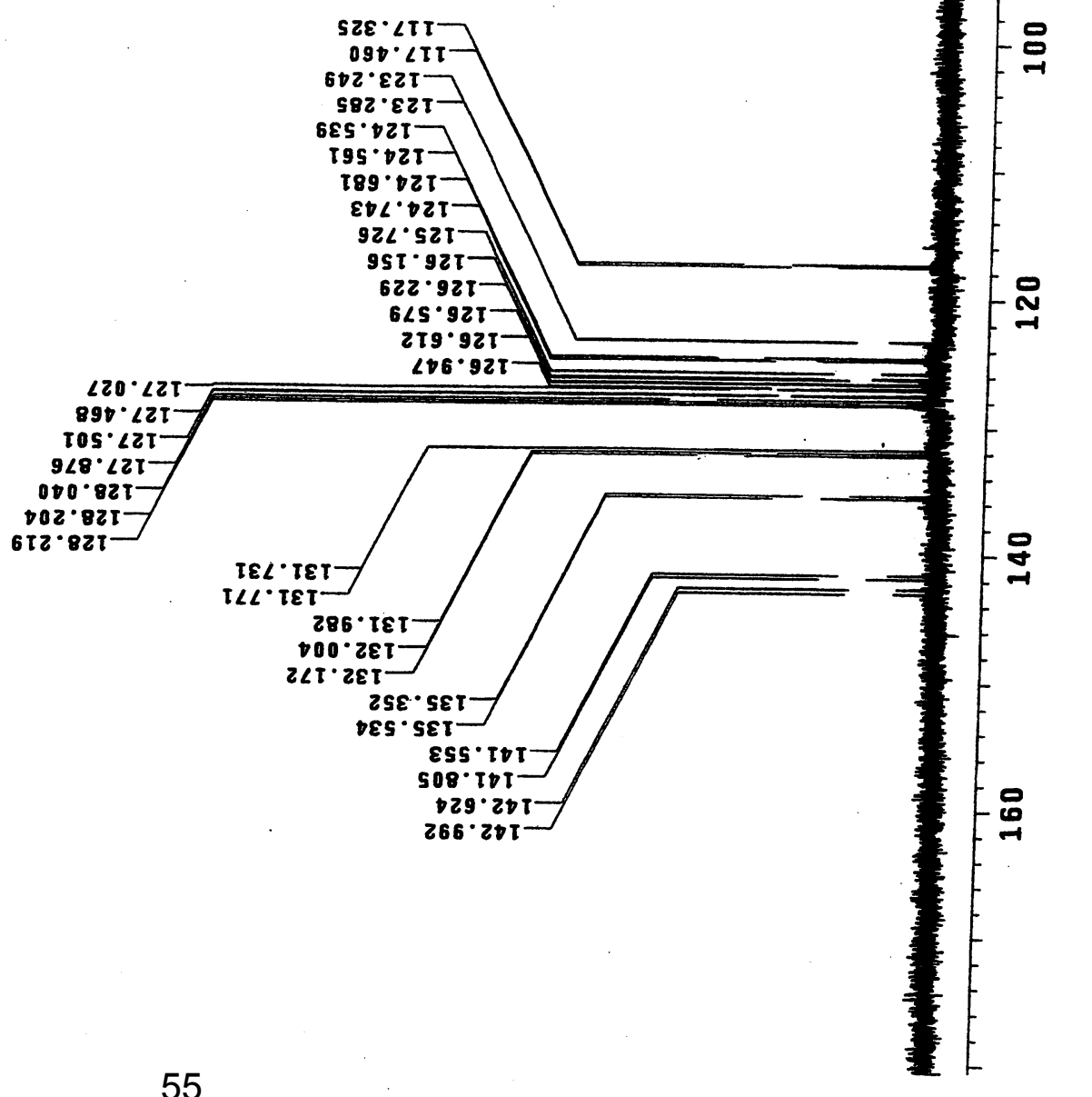




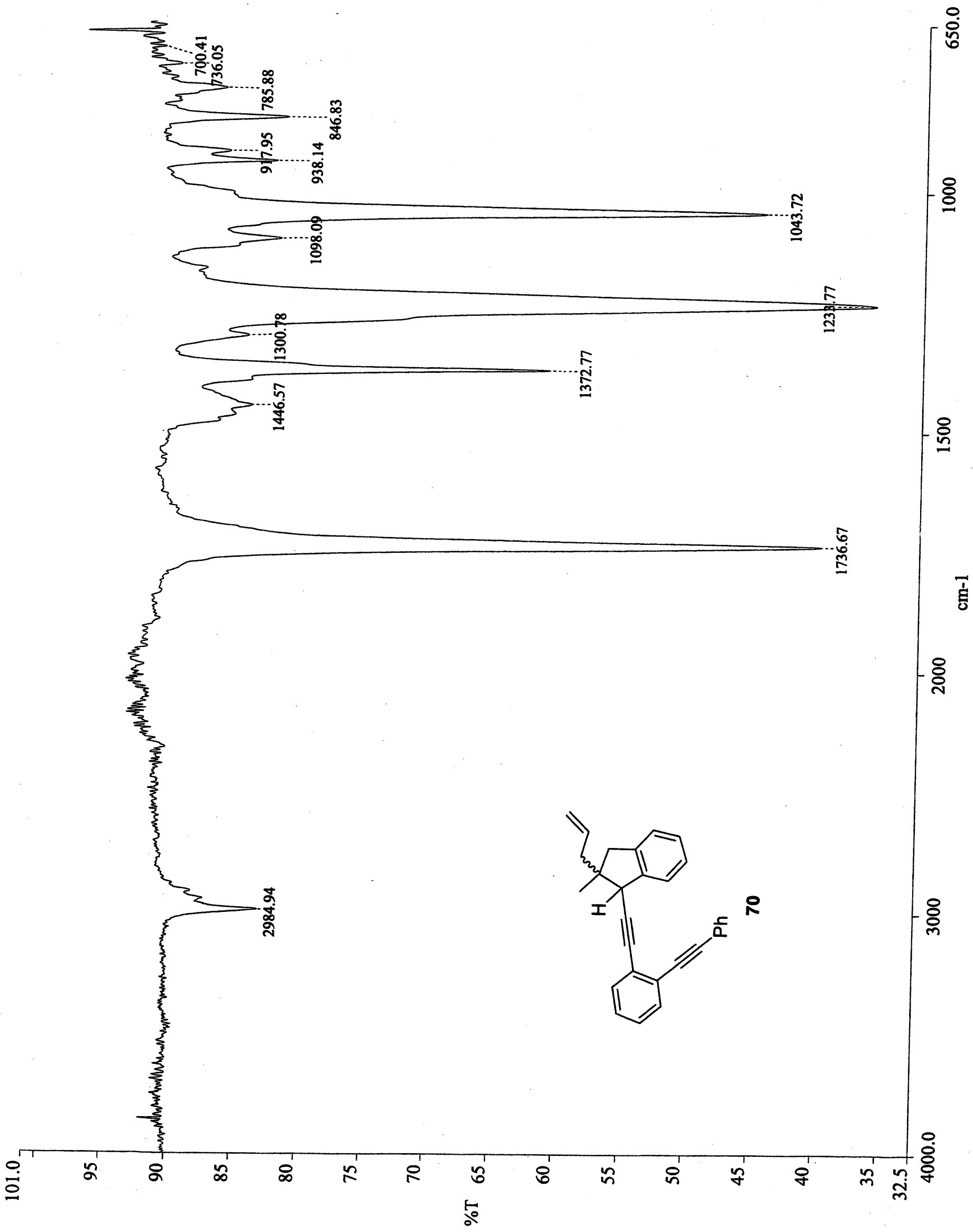




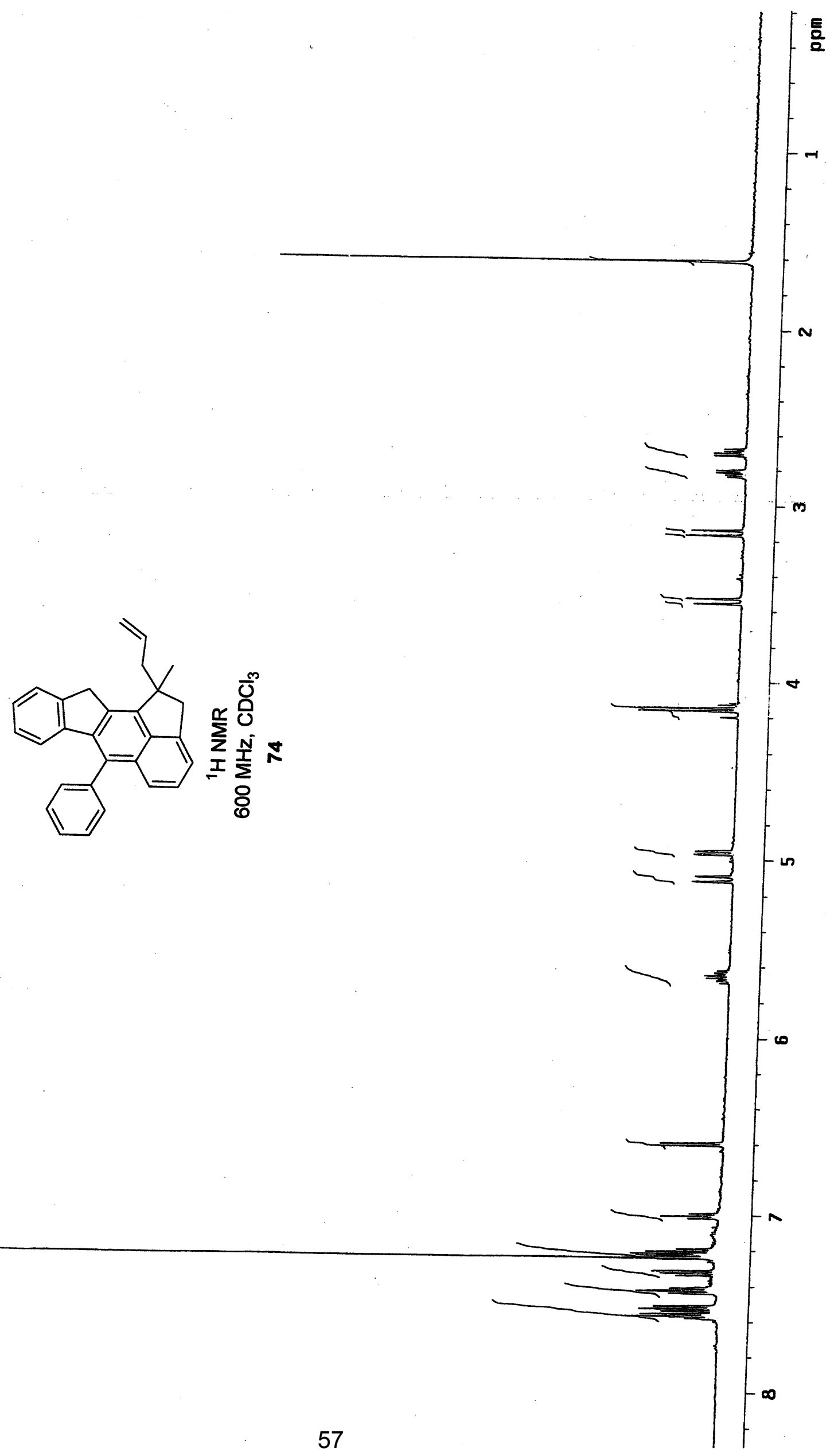




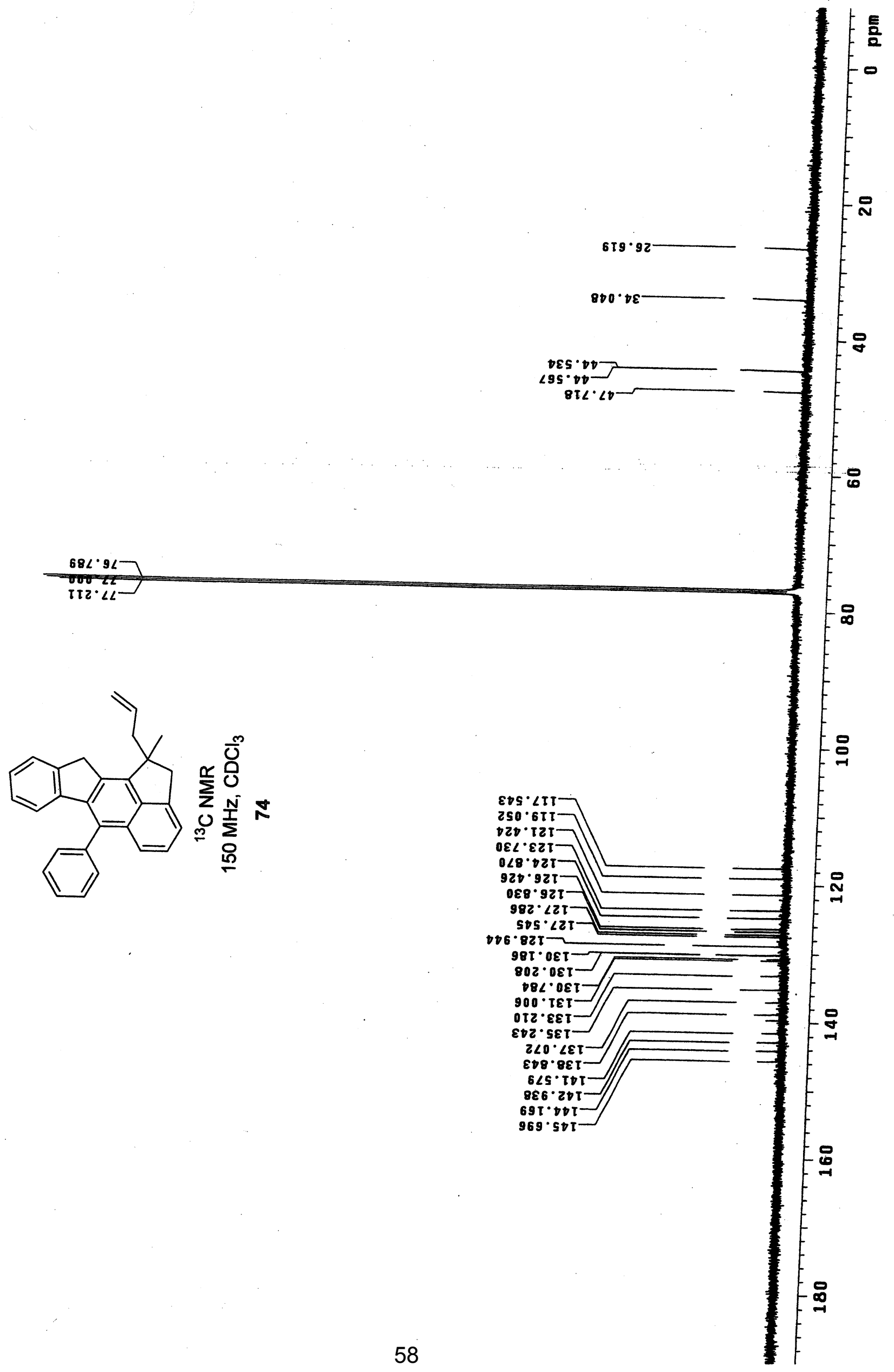




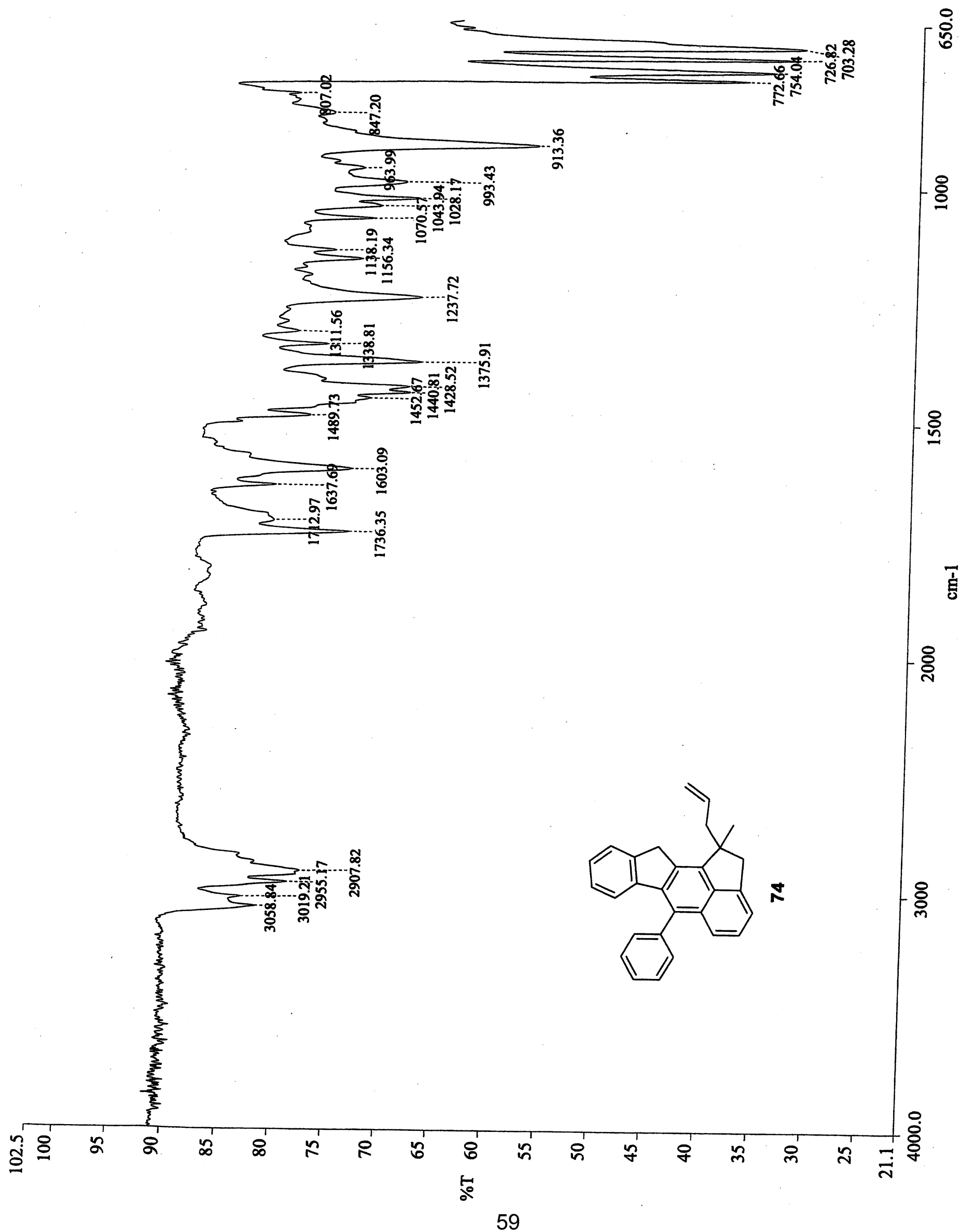




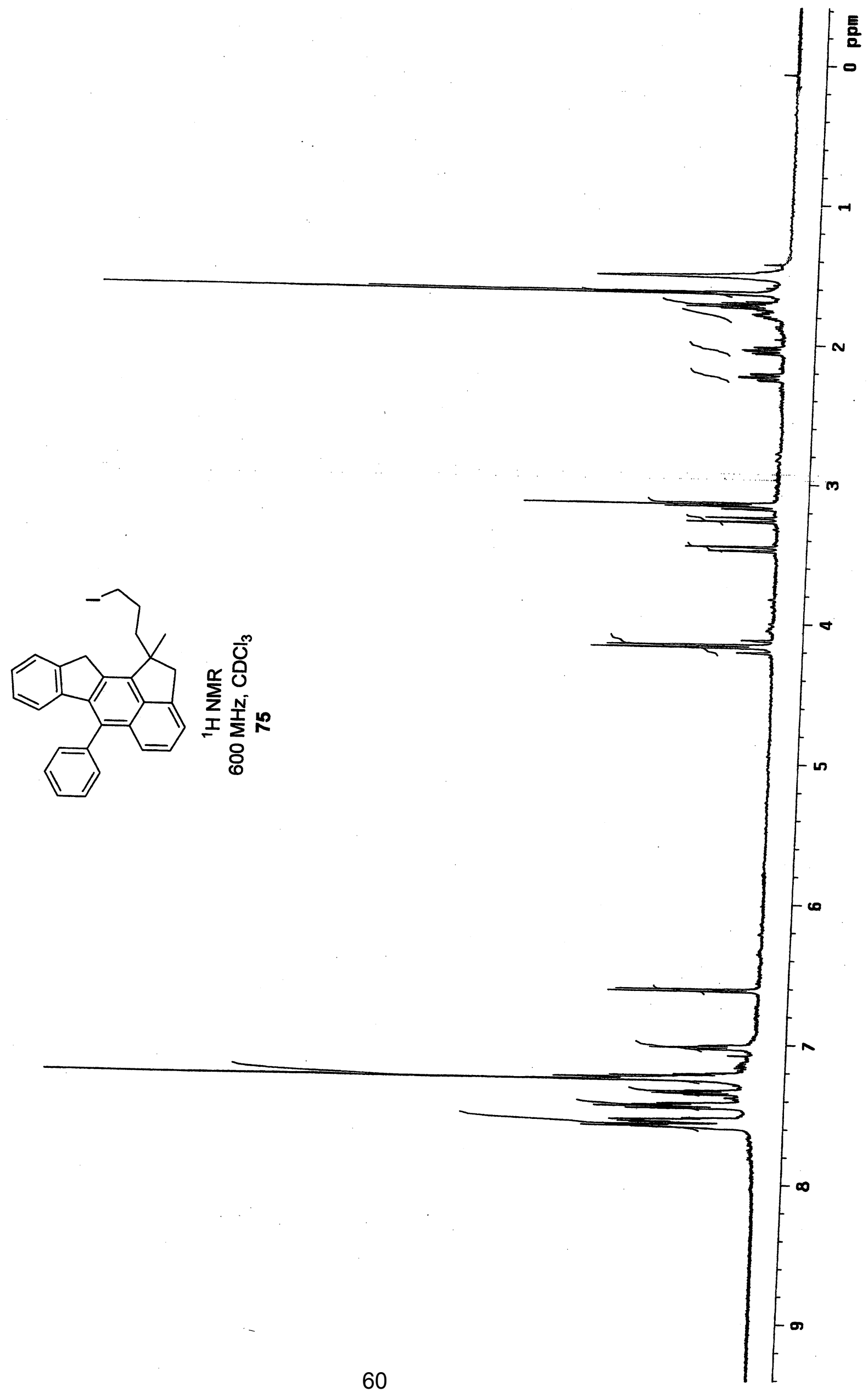




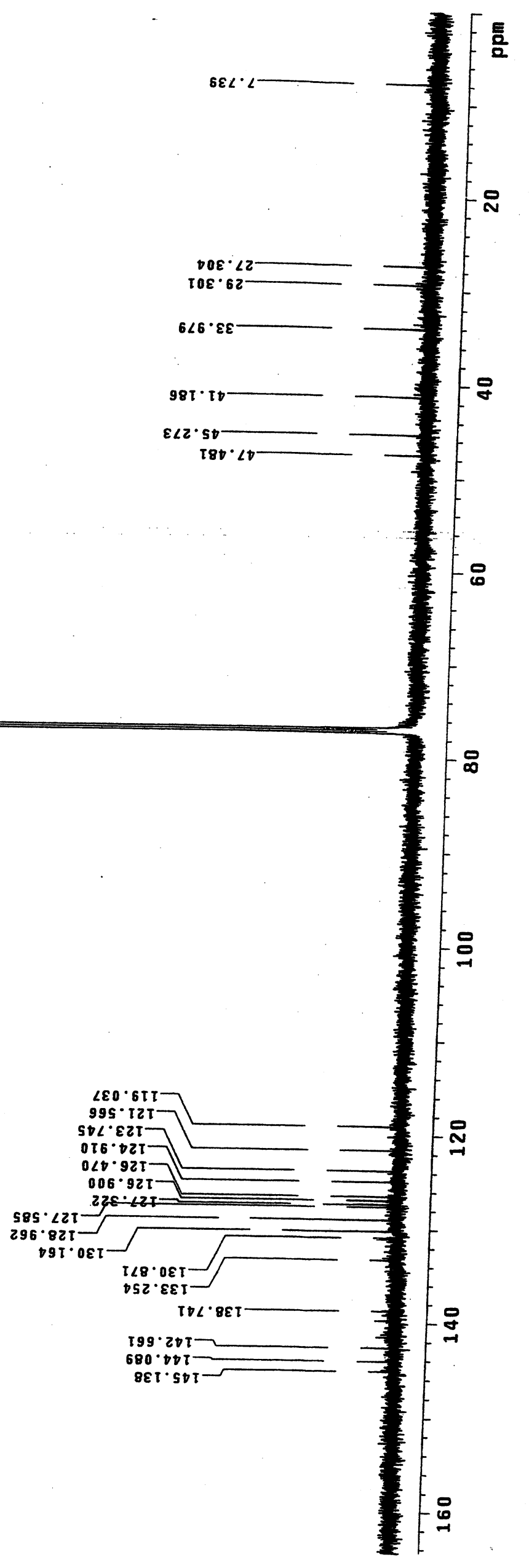




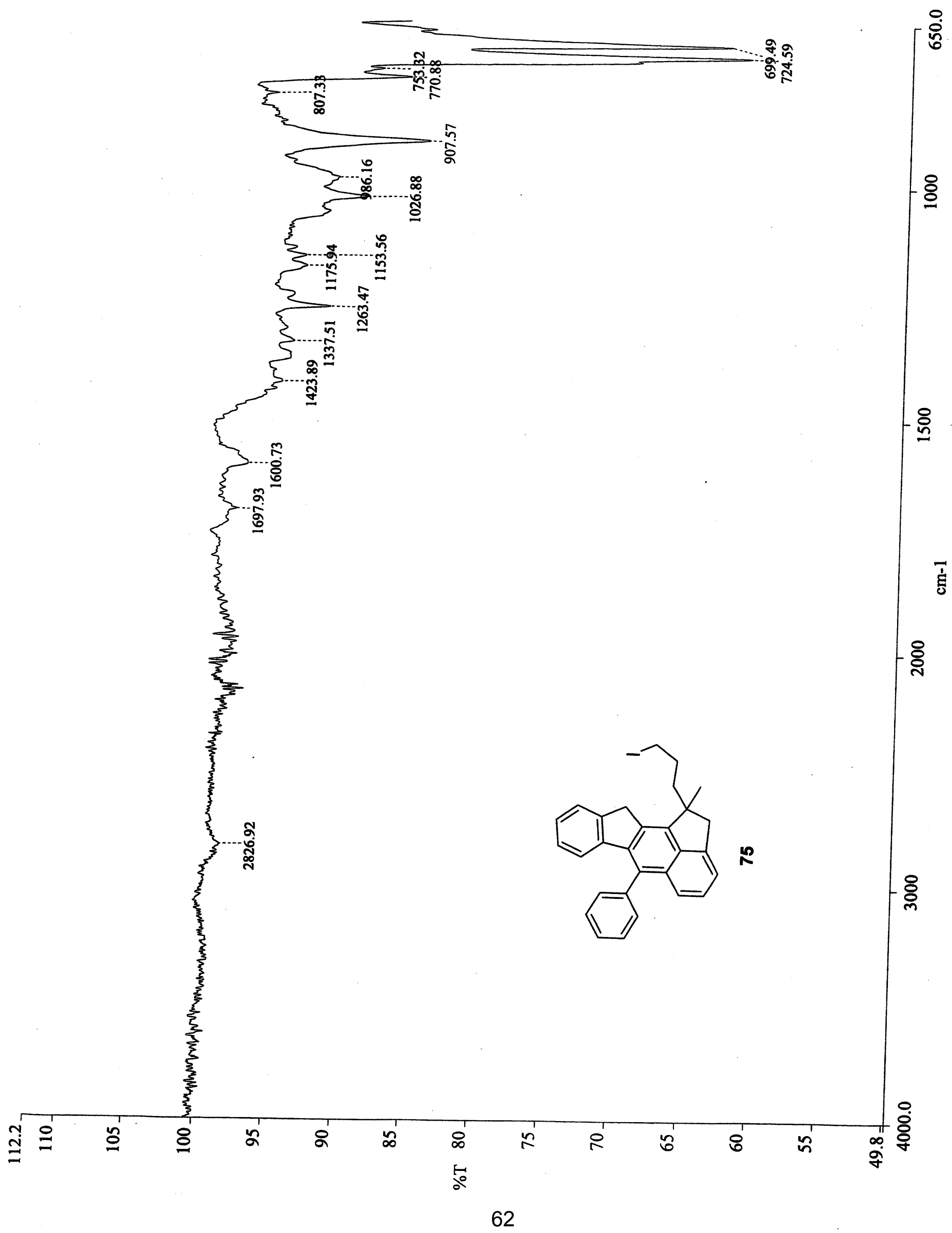




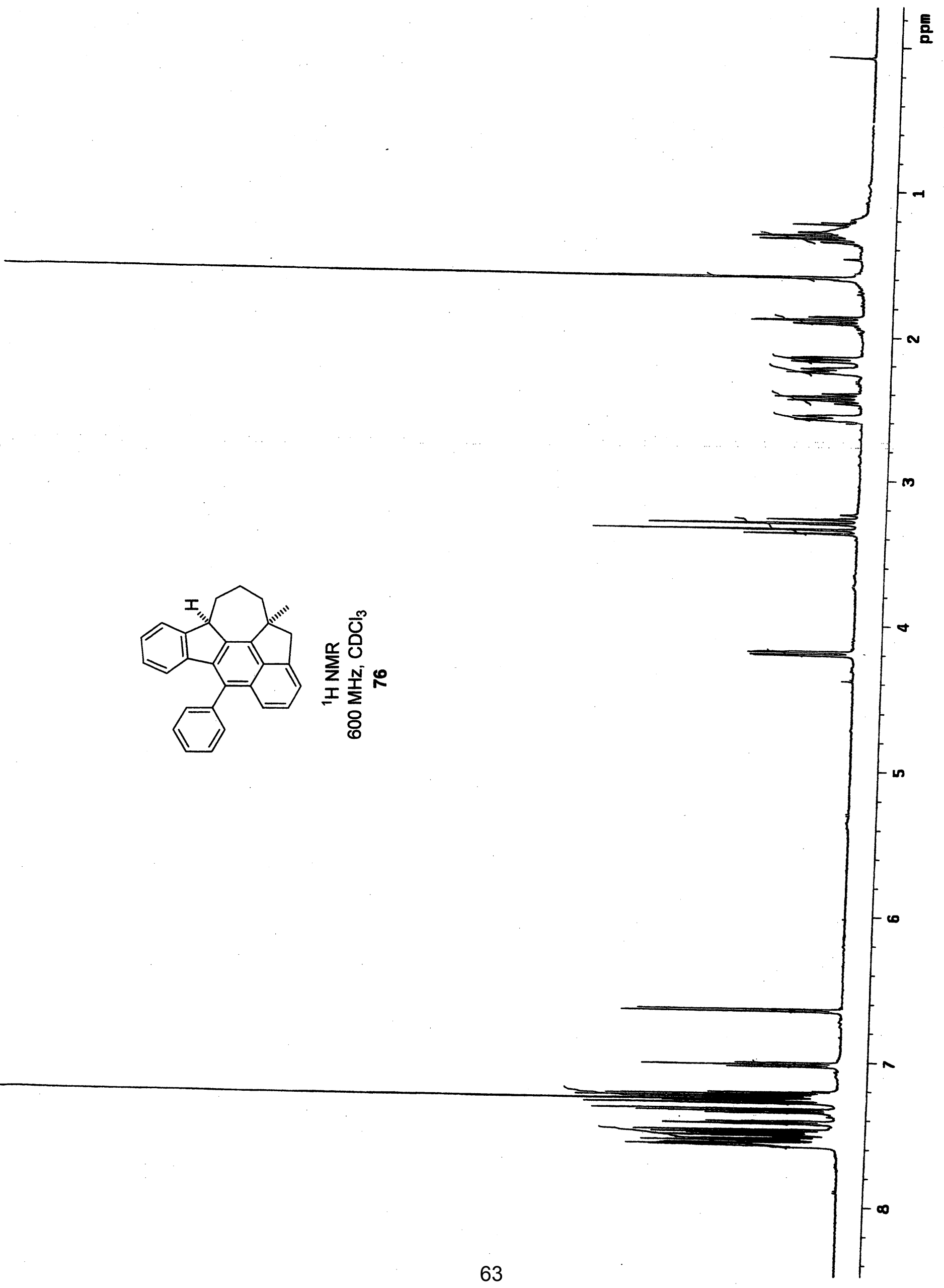




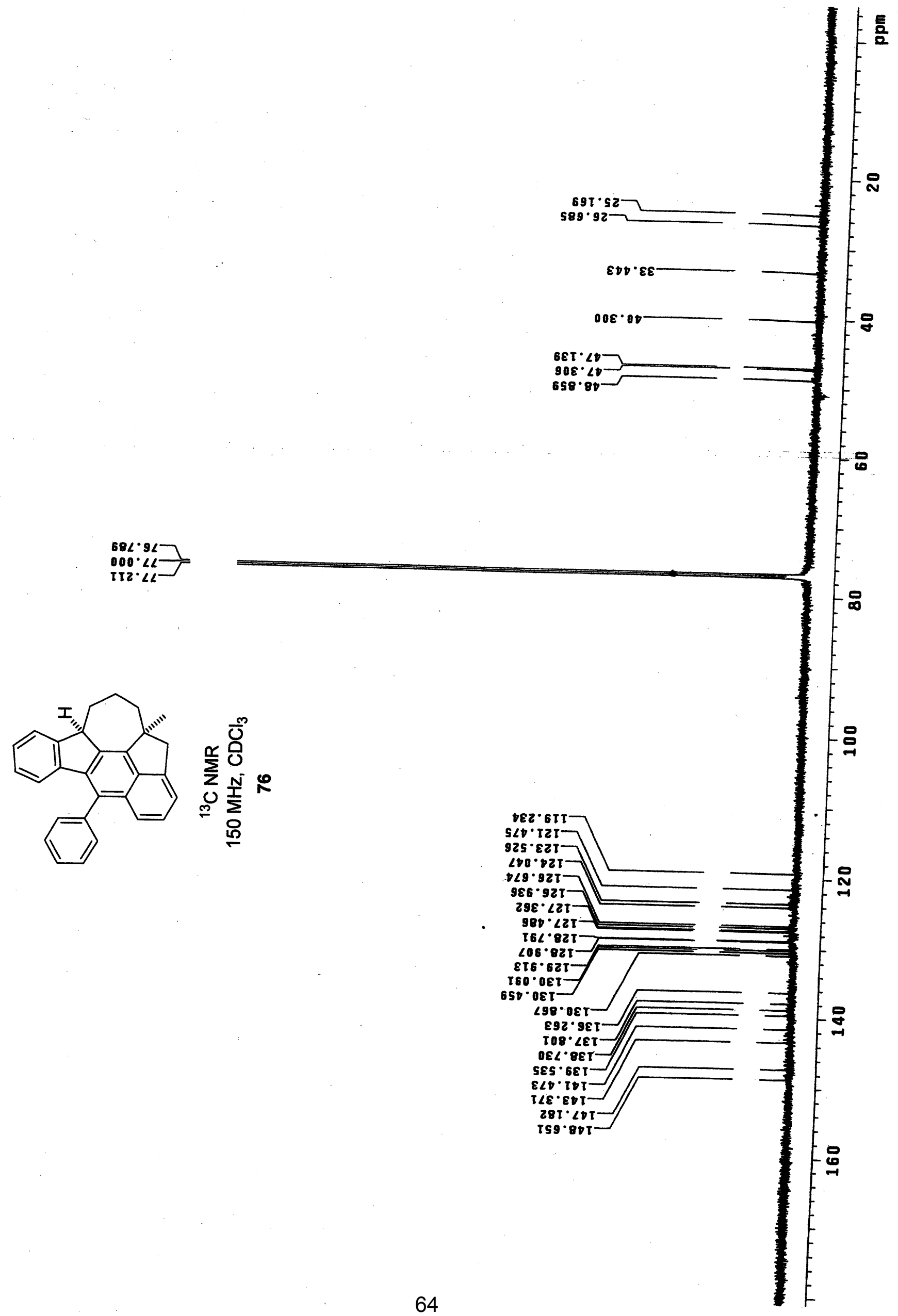




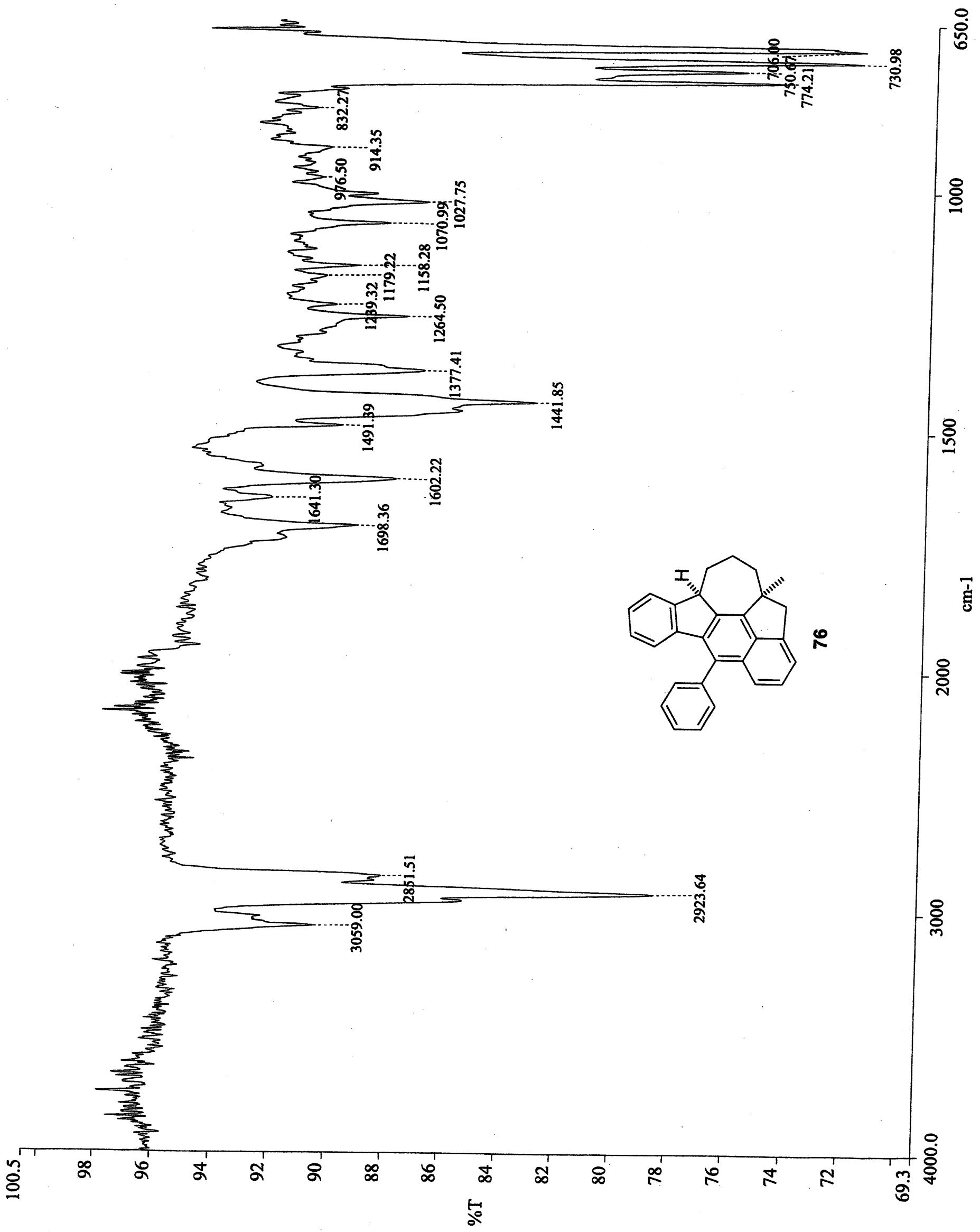

